\title{
Environmental niches and metabolic diversity in Neoarchean lakes
}

\author{
E.E. Stüeken ${ }^{1,2,3,4 *}$, R. Buick ${ }^{2,3}$, R.E. Anderson ${ }^{2,5}$, J.A. Baross ${ }^{2,6}$, N.J. Planavsky ${ }^{7}$, T.W. Lyons ${ }^{4}$
}

1. present address: School of Earth \& Environmental Sciences, University of St. Andrews, St Andrews, Fife, KY16 9AL, Scotland, UK

2. NASA Astrobiology Institute, Virtual Planetary Laboratory, University of Washington, Seattle WA 98195, USA

3. Department of Earth \& Space Sciences, University of Washington, Seattle WA 98195-1310, USA

4. Department of Earth Sciences, University of California, Riverside CA 92521, USA

5. Department of Biology, Carleton College, Northfield MN 55057, USA

6. School of Oceanography, University of Washington, Seattle WA 98195, USA

7. Department of Geology and Geophysics, Yale University, New Haven CT 06520, USA

\begin{abstract}
The diversification of macro-organisms over the last 500 million years often coincided with the development of new environmental niches. Microbial diversification over the last 4 billion years likely followed similar patterns. However, linkages between environmental settings and microbial ecology have so far not been described from the ancient rock record. In this study we investigated carbon, nitrogen and molybdenum isotopes and iron speciation in five non-marine stratigraphic units of the Neoarchean Fortescue Group, Western Australia, that are similar in age (2.78-2.72 Ga) but differ in their hydro-geologic setting. Our data suggest that the felsic-dominated and hydrologically open lakes of the Bellary and Hardey formations were probably dominated by methanogenesis $\left(\delta^{13} \mathrm{C}_{\mathrm{org}}=-38.7 \pm 4.2 \%\right.$ o $)$ and biological $\mathrm{N}_{2}$ fixation $\left(\delta^{15} \mathrm{~N}_{\text {bulk }}=-0.6 \pm 1.0 \%\right)$, whereas the Mt. Roe, Tumbiana and Kylena Formations, with more mafic siliciclastic sediments, preserve evidence of methanotrophy $\left(\delta^{13} \mathrm{C}_{\text {org }}\right.$ as low as $-57.4 \%, \delta^{13} \mathrm{C}_{\text {carb }}$ as low as $-9.2 \%$ ) and $\mathrm{NH}_{3}$ loss under alkaline conditions. Evidence of oxygenic photosynthesis is recorded only in the closed evaporitic Tumbiana lakes marked by abundant stromatolites, limited evidence of $\mathrm{Fe}$ and $\mathrm{S}$ cycling, fractionated Mo isotopes $\left(\delta^{98 / 95} \mathrm{Mo}=+0.4 \pm 0.4 \%\right)$ and the widest range in $\delta^{13} \mathrm{C}_{\text {org }}(-57 \%$ to $-15 \%$ ), suggesting oxidative processes and multiple carbon fixation pathways. Methanotrophy in the three mafic settings was probably coupled to a combination of oxidants, including $\mathrm{O}_{2}$ and $\mathrm{SO}_{4}{ }^{2-}$. Overall, our results may indicate that early microbial evolution on the Precambrian Earth was in part influenced by geological parameters. We speculate that expanding habitats, such as those linked to continental growth, may have been an important factor in the evolution of life.
\end{abstract}

\section{Introduction}

The paleontological record of plants and animals has demonstrated that diversification of macro-organisms was often facilitated by the provision of new environmental niches (Benton, 1995). A famous example includes the colonization of continental habitats, driven by evolutionary adaptations to higher solar radiation, desiccation and highly variable water chemistry (Little, 1990; Kenrick \& Crane, 1997). Since then, continents have been important localities for the origination of new species, at least partly driven by the immense environmental heterogeneity of land surfaces (Stein et al., 2014). With the advent of next-generation sequencing, it has become increasingly clear that similar environmental selection effects also operate on Bacteria and Archaea and shape 
microbial diversity on spatial scales ranging from millimeters to hundreds of kilometers (HornerDevine et al., 2004; Smith et al., 2005; Martiny et al., 2006). Experimental work has confirmed that Bacteria and Archaea can adapt and speciate rapidly in response to environmental gradients (Rainey \& Travisano, 1998), and similar to plants and animals, they appear to be dispersal-limited and may be constrained by geographic barriers (Whitaker et al., 2003). Hence, it is conceivable that the earliest diversification of microbial life in the Archean (e.g., David \& Alm, 2011) was also driven to some extent by the diversity of environmental niches.

To test this hypothesis, we turned to the Neoarchean lower Fortescue Group (2.78-2.72 Ga) in Western Australia (Fig. 1), which comprises a sequence of igneous and sedimentary rock units that are typically interpreted as being deposited in non-marine environments and that capture several distinct sets of environmental conditions (Blake et al., 2004). The mineralogy of the detrital sediment is highly variable, with a mostly felsic source for the Bellary and Hardey formations and a mafic source for the Mt. Roe, Kylena and Tumbiana formations. While the Kylena and Tumbiana formations are carbonate-rich and likely represent large stagnant evaporative lakes, the Bellary and Hardey formations represent open fluvio-lacustrine systems (Blake, 1993), and the Mt. Roe formation has only small shallow ephemeral ponds (Rye \& Holland, 2000). This set of environmental niches is not unique to the Neoarchean, but it creates a window into diverse microbial habitats a few hundred million years before the Paleoproterozoic rise of atmospheric oxygen (Lyons et al., 2014).

We hypothesize that this diversity of environmental settings resulted in biogeographic patterns in microbial ecology. We addressed this question with a range of geochemical tools including carbon and nitrogen isotopes, molybdenum isotopes, iron speciation and trace element abundances to test for variation in metabolic strategies, nutrient supply and redox settings. Many of these stratigraphic units have previously been investigated in separate geochemical studies (Buick, 1992; Rasmussen \& Buick, 1999; Rye \& Holland, 2000; Eigenbrode \& Freeman, 2006; Bolhar \& van Kranendonk, 2007; Thomazo et al., 2009; Thomazo et al., 2011; Coffey et al., 2013; Wille et al., 2013; Flannery et al., 2014; Stüeken et al., 2015a; Stüeken et al., 2015b; Slotznick \& Fischer, 2016) but have so far not been compared within an environmental context. We provide previously unrecognized correlations among microbial metabolism, redox conditions, hydrological settings and geological substrate on Neoarchean land surfaces.

\section{Geological Setting}

The Fortescue Group rests unconformably on the Pilbara craton in the northwest of Western Australia (Blake \& Barley, 1992; Blake et al., 2004). The lower part, which was the focus of this study, comprises three subaerial flood basalt sequences (Mt. Roe, Kylena, Maddina) that are separated by terrigenous sedimentary units (Fig. 2). Accommodation space for the sediments was probably created by WNW-ESE extension of the craton, which progressively opened up a series of half-grabens. The flood basalts are thought to be analogous to Phanerozoic flood basalts associated with continental rifting (Barley et al., 1992). The metamorphic grade of these rocks is relatively low-sub-greenschist facies specifically-and thus well suited to our study (Smith $e t$ al., 1982).

\subsection{Bellary Formation}

The basal unit of the Fortescue Group is the Bellary Formation, which remains undated and is composed of siliciclastic sediments, including conglomerates, diamictites and thin mudstones. It rests unconformably on granitoids and gneisses, which provide a maximum age of 
$2.85 \mathrm{Ga}$ (Hall, 2005). Although basalt overlies the unconformity in many areas, the source terrain of the sediments is dominated by granite and other felsic lithologies of the Pilbara craton, as evidenced by the felsic composition of conglomeratic clasts (Fig. 3a). We did not observe basalt close to our sampling sites. The setting of Bellary Formation has been interpreted as fluviolacustrine with local alluvial fans (Barley et al., 1992; Blake, 1993) filling paleo-valleys cut into the unconformity surface with relief of up to several hundred meters and a lateral extent of several kilometers (Blake, 1993).

\subsection{Mt. Roe Formation}

The overlying Mt. Roe basalt contains discontinuous (less than a few kilometers along strike) siliciclastic and volcaniclastic sedimentary beds that are few meters thick and separate individual basalt flows. Silty mudrocks are typically graded and moderately sorted (Fig. 3c), suggesting pulsed, perhaps storm-controlled deposition into standing water. The sediments contain abundant opaque particles that likely represent devitrified volcanic glass eroded from basaltic flow tops (Fig. 3b). Paleosols on some of the basalt flows further support the non-marine depositional setting (e.g., Macfarlane et al., 1994; Rye \& Holland, 2000). Leaching of ferrous iron from these paleosols indicates anoxic conditions at $2.77 \mathrm{Ga}$ (Yang et al., 2002). Deposition apparently occurred in shallow, short-lived (ephemeral) ponds rather than deep perennial lakes (Rye \& Holland, 2000) with sedimentation occurring in distinct pulses from a very local source.

\subsection{Hardey Formation}

The Hardey Formation overlies the Mt. Roe Formation and is dominated by sandstone with subordinate conglomerates and mudrocks. It is interrupted by a felsic porphyry unit. Detrital grains in the Hardey Formation are predominantly composed of quartz and feldspar (Fig. 3d), reflecting a felsic provenance (Blake, 1993). The depositional environment is interpreted to be an open, braided fluvial system, based on the moderate degree of sorting and unidirectional current ripples and trough cross-bedding in sandstones, indicating one predominant direction of water flow-as in a river (Blake, 1993) (Fig. 3f). As for the Mt. Roe, mudrocks of the Hardey Fm are commonly graded (Fig. 3e) and probably represent overbank deposits or ephemeral lakes, indicated by their symmetrical and truncated wave ripples (Fig. 3f). The mudrock units are mostly less than 10 meters thick and extend laterally for no more than a few kilometers. The conglomeratic units contain deposits of heavy minerals, including pyrite, siderite and uraninite, which attest to an oxygendepleted atmosphere at the time of deposition around 2.75-2.76 Ga (Rasmussen \& Buick, 1999; Hall, 2005).

\subsection{Kylena basalt, Mopoke Member}

The Kylena basalt above the Hardey Formation contains the Mopoke Member, a thin ( 10meter-thick) stromatolitic carbonate unit that crops out discontinuously (Fig. 3g). The continuity along strike for many segments is less than 10 kilometers. The carbonate is largely calcite with minor dolomite (Flannery et al., 2014, this study). The carbonates of the Mopoke Member are interlaminated with shale that includes volcaniclastic material, likely derived from the Kylena basalt vents. Patterns for rare earth elements in the carbonates suggest a non-marine depositional setting (Bolhar \& van Kranendonk, 2007), whereas occurrences of mud-drapes over symmetric wave ripples and relatively heavy $\delta^{13} \mathrm{C}_{\text {org }}$ values compared to the lacustrine Tumbiana Formation have been interpreted as evidence of either a marine influence or a distinct lake (Flannery et al., 2014). As further investigation shows that carbon and nitrogen isotope data are indeed similar to 
those of the Tumbiana Formation (discussed below) (Stuieken et al., 2015b), we tend toward the lacustrine interpretation.

\subsection{Tumbiana Formation}

The Tumbiana Formation is a thick sequence (several hundred meters in many places) of tuffaceous wacke, mudrock and carbonate that extends for hundreds of kilometers across the Pilbara Craton. This continuity is broken up by NNE-trending growth faults, which fragment the sites of deposition into separate sub-basins many tens of kilometers across. The carbonate consists mostly of calcite (Buick, 1992, this study) and is commonly stromatolitic (Fig. 3h). Siliciclastic sediments with felsic mineralogies are rare but present, with trough cross-bedding suggesting a fluvial source in this case. Multiple lines of evidence indicate a lacustrine setting, including the abundance of desiccation cracks and teepees (Fig. 3i), rapid lateral and vertical facies changes (Buick, 1992; Awramik \& Buchheim, 2009), the absence of tidal indicators (cf. Sakurai et al., 2005; Awramik \& Buchheim, 2009), the scarcity of dolomite and the absence of gypsum despite the presence of halite (Buick, 1992), elevated and variable ${ }^{87} \mathrm{Sr} /{ }^{86} \mathrm{Sr}$ ratios (Awramik \& Buchheim, 2009) and the absence of Y and Gd anomalies and the presence of variable slopes in REE patterns (Bolhar \& van Kranendonk, 2007; Coffey et al., 2013). The microbial mats and stromatolites were likely produced by cyanobacteria, as indicated by the morphology of tufted mats (Flannery \& Walter, 2012) and the scarcity of sulfides and other authigenic iron minerals suggesting that $\mathrm{H}_{2} \mathrm{~S}$ and ferrous iron were not available as electron donors for anoxygenic phototrophs (Buick, 1992). The lack of $\mathrm{Ce}$ anomalies suggests that oxygen did not build up in the water column (Coffey et al., 2013). Individual stromatolites may have a synoptic relief of up to 2 meters, indicating that water was at least that deep for prolonged periods.

\section{Methods}

In addition to compiling data from the literature, we made new measurements of samples from the Hardey, Mt. Roe, Kylena and Tumbiana formations. Geochemical measurements followed standard protocols and therefore will only be described briefly.

\subsection{Sample collection and preparation}

Samples of the Bellary and Kylena formations and some samples of the Tumbiana and Hardey formations were collected from outcrop in the field (Stuieken et al., 2015b). We obtained additional samples of the Mt. Roe Formation, the Hardey Formation and the Tumbiana Formation from drill cores obtained as part of the NASA Astrobiology Drilling Project (cores ABDP-6, ABDP-3, ABDP-10). We also included Tumbiana samples from core SV-1 and WRL-1 (Stiueken et al., 2015b). Weathering rinds and the outer surfaces of drill-core samples were removed with a rock saw. The rocks were then crushed into cm-sized chips, cleaned with alcohol, $2 \mathrm{~N} \mathrm{HCl}$ and DI$\mathrm{H}_{2} \mathrm{O}(18 \mathrm{M} \Omega)$ and pulverized with a $\mathrm{Al}_{2} \mathrm{O}_{3}$-ceramic puck mill. Powders were stored in scintillation vials that had been baked out in the muffle furnace at $500^{\circ} \mathrm{C}$ overnight.

\subsection{Geochemical analyses}

\subsubsection{Organic carbon and nitrogen isotopes}

Carbon and nitrogen isotope measurements were performed in the University of Washington Isolab following protocols described by Stüeken et al. (2013; 2015a; 2015b). For organic carbon and bulk nitrogen, powders were decarbonated with $6 \mathrm{~N} \mathrm{HCl}$ (reagent grade, applied three times at $60^{\circ} \mathrm{C}$ overnight), rinsed three times with $\mathrm{DI}-\mathrm{H}_{2} \mathrm{O}(18 \mathrm{M} \Omega)$ and dried in a closed oven 
for two days. Dry powders were analyzed by flash-combustion with an elemental analyzer (Costech) coupled to a continuous-flow IRMS (Thermo MAT253). Data were corrected by twopoint normalization with calibrated in-house standards (Paul et al., 2007). Analytical precision was $0.18 \%$ o for $\delta^{13} \mathrm{C}_{\text {org }}$ and $0.50 \%$ for $\delta^{15} \mathrm{~N}$, as determined by the standard deviation of replicate samples. Relative precisions of $\mathrm{C}$ and $\mathrm{N}$ concentrations were $1 \%$ and $4 \%$, respectively. Long-term isotopic precision over several weeks was monitored with our in-house rock standard UW-McRae, for which we obtained a value of $5.22 \pm 0.20 \%$ for $\delta^{15} \mathrm{~N}$ and $-37.83 \pm 0.10 \%$ for $\delta^{13} \mathrm{C}_{\text {org }}$ - in good agreement with previous studies (5.51 $\pm 0.19 \%$ and $-37.89 \pm 0.21 \%$, Stüeken et al., 2015a). Carbon and nitrogen isotope data are reported in standard delta notation, referenced to VPDB for C and to atmospheric $\mathrm{N}_{2}$ for $\mathrm{N}$.

\subsubsection{Carbonate carbon and oxygen isotopes}

For carbonate-bound carbon and oxygen isotopes, untreated powders were weighed into glass vials and reacted with concentrated phosphoric acid at $80^{\circ} \mathrm{C}$ in a Kiel III Carbonate-Device. The resulting $\mathrm{CO}_{2}$ gas was purified cryogenically and analyzed with a dual-inlet IRMS (Thermo Finnigan Delta Plus). As for carbon and nitrogen isotopes, we used a two-point calibration to correct the raw data. The average precision was $0.04 \%$ for both $\delta^{13} \mathrm{C}_{\text {carb }}$ and $\delta^{18} \mathrm{O}_{\text {carb }}$. We assumed calcite mineralogy for the oxygen isotope measurements, as confirmed by high molar $\mathrm{Ca} / \mathrm{Mg}$ ratios measured in $\mathrm{Na}$-acetate extracts (range 4 to 283, median 40, excluding samples with less than $2 \%$ carbonate; see below). The $\mathrm{CO}_{2}$ gas pressure was calibrated for carbonate quantity (relative precision 6.4\%). Carbon and oxygen isotope data are reported in standard delta notation, referenced to VPDB for $\mathrm{C}$ and $\mathrm{O}$.

\subsubsection{Elemental abundances}

Elemental abundances and iron speciation were measured at the University of California, Riverside (Reinhard et al., 2013). Aliquots of untreated rock powder were first ashed in ceramic crucibles $\left(800^{\circ} \mathrm{C}\right.$ overnight) and then digested in Teflon beakers with $4 \mathrm{ml} \mathrm{HNO}_{3}$ and $1 \mathrm{ml} \mathrm{HF}$ at $120^{\circ} \mathrm{C}$ overnight. Fluoride precipitates were removed with $1-2$ treatments with aqua regia $(3 \mathrm{ml}$ $\mathrm{HCl}+1 \mathrm{ml} \mathrm{HNO}_{3}$ ). All acids were concentrated and trace-metal grade. Sample residues were stored in $5 \%(\mathrm{v} / \mathrm{v}) \mathrm{HNO}_{3}$. Elemental analyses were performed by ICP-MS (Agilent 7500ce). Average precision for all elements was 6\%. Measured concentrations of the USGS rock standard SCo-1 agreed to with $7 \%$ with nominal values. Enrichment factors $(\mathrm{EF})$ for trace elements $(\mathrm{X})$ relative to continental crust were calculated as $\mathrm{EF}_{\mathrm{x}}=\left(\left[\mathrm{X}_{\text {sample }}\right] /\left[\mathrm{Al}_{\text {sample }}\right]\right) /\left(\left[\mathrm{X}_{\text {crust }}\right] /\left[\mathrm{Al}_{\text {crust }}\right]\right)$, where concentrations in average upper continental crust were taken from Rudnick \& Gao (2014).

\subsubsection{Iron speciation}

For the extraction of different iron phases, around 100mg of powder were treated sequentially with sodium acetate $(1 \mathrm{M}, 10 \mathrm{ml}$, buffered to $\mathrm{pH} 4.5$ with acetic acid, $48 \mathrm{~h})$, sodium dithionite $(50 \mathrm{~g} / \mathrm{L}, 10 \mathrm{ml}$, buffered to $\mathrm{pH} 4.8$ with $0.35 \mathrm{M}$ acetic acid and $0.2 \mathrm{M}$ sodium citrate, $2 \mathrm{~h}$ ) and ammonium oxalate $\left(0.2 \mathrm{M}, 10 \mathrm{ml}\right.$, buffered to $\mathrm{pH} 3.2$ with $\left.0.17 \mathrm{M} \mathrm{NH}_{4} \mathrm{OH}, 6 \mathrm{~h}\right)$ to extract iron from carbonates, ferric oxides and magnetite, respectively (Poulton \& Canfield, 2005; Reinhard et al., 2009; Reinhard et al., 2013). For each treatment, the samples were placed on a shaker table with the reagent at room temperature and then centrifuged. An aliquot of the supernatant was saved for analyses of iron contents by ICP-MS (Agilent 7500ce). Pyrite-bound iron was determined using the Cr-reduction method with a separate powder aliquot (Canfield et al., 1986). Around 0.5-2g of powder were reacted with hot $\mathrm{CrCl}_{2}(1 \mathrm{M}$ in $0.5 \mathrm{M} \mathrm{HCl}, 35 \mathrm{ml})$ and concentrated $\mathrm{HCl}(15 \mathrm{ml})$ in one 
step under $\mathrm{N}_{2}$ gas for $2 \mathrm{~h}$, and the resulting $\mathrm{H}_{2} \mathrm{~S}$ gas was trapped with zinc acetate. The abundance of sulfur was determined by iodometric titration (Canfield et al., 1986). We assumed an $\mathrm{FeS}_{2}$ stoichiometry to calculate the concentration of pyrite Fe from measured values of pyrite $S$. The precision was $7 \%$ on average. The sum of all extracts in each sample, including pyrite-bound iron (FepY) is defined as the total amount of 'highly reactive iron' $\left(\mathrm{Fe}_{\mathrm{HR}}\right)$.

\subsubsection{Molybdenum isotopes}

Molybdenum isotopes were measured at Yale University following established protocols (Asael et al., 2013; Planavsky et al., 2014). An aliquot of the bulk digest was doped with a ${ }^{97}$ Mo${ }^{100}$ Mo double spike, targeting a spike/sample molybdenum ratio of 1 . The molybdenum was purified from matrix elements with two ion-exchange columns (AG-MP-1M and AG50W-X8) and analyzed by multi-collector ICP-MS (Thermo Neptune) at Mo concentrations of 50ppb. Isotopic ratios are expressed in $\delta^{98 / 95} \mathrm{Mo}(\% \mathrm{o})=1000 \cdot\left[\left({ }^{98} \mathrm{Mo} /{ }^{95} \mathrm{Mo}\right)_{\text {sample }} /\left({ }^{98} \mathrm{Mo} /{ }^{95} \mathrm{Mo}\right)_{\mathrm{NIST} 3134}\right.$ - 1$]$, where NIST 3134 was set to $+0.25 \%$ as proposed by Nägler et al. (2014). We obtained a value of -0.41 $\pm 0.03 \%$ o $(1 \sigma)$ for the USGS reference standard NOD-1, in good agreement with previous work ($0.42 \pm 0.02 \%$, Asael et al., 2013). The average standard deviation of sample replicates was $0.03 \%$ o $(1 \sigma)$.

\section{Results}

\subsection{Carbon isotopes}

Analytical results are tabulated in the Appendix.

New organic and inorganic $\delta^{13} \mathrm{C}$ values for the Tumbiana Formation range from $-57.4 \%$ to $-36.3 \%$ and $-6.8 \%$ o to $+1.0 \%$, respectively, similar to previous results $(-57.1 \%$ o to $-15.0 \%$ and 9.2\% to +1.9\%o, Eigenbrode \& Freeman, 2006; Thomazo et al., 2009; Stüeken et al., 2015b). Low $\delta^{13} \mathrm{C}_{\text {carb }}$ values tend to occur primarily in mudrocks with less than $40 \%$ carbonate and associated with light $\delta^{13} \mathrm{C}_{\text {org }}$ values (Fig 3). Inorganic $\delta^{13} \mathrm{C}$ in the Kylena Formation $(-1.9 \%$ to $+2.9 \%$ ) is broadly similar to that of the Tumbiana Formation and in good agreement with measurements by Flannery et al. (2014) (-5.7\%o to $+2.1 \%$ o). In the Hardey and Bellary formations, where carbonate is rare, $\delta^{13} \mathrm{C}_{\text {org }}$ values (-42.3\%o to $-24.9 \%$, Watanabe et al., 2004; Stiueken et al., 2015a) fall toward the heavier end of the range seen in the Tumbiana Formation. The Mt. Roe Formation has light $\delta^{13} \mathrm{C}_{\text {org }}$ values $(-55.3 \%$ o to $-50.1 \%$ ) similar to those of the Tumbiana and Kylena formations (Flannery et al., 2014; Stüeken et al., 2015b, this study), albeit with much less scatter.

\subsection{Nitrogen isotopes}

New nitrogen isotope data from the ABDP-3 drill core from the Hardey Formation $\left(\delta^{15} \mathrm{~N}\right.$ $=-2.3 \%$ to $+1.8 \%$ o $)$ agree well with those previously obtained from outcrop samples $(-2.2 \%$ to $+0.7 \%$, Stüeken et al., 2015a). Nitrogen isotope data from the Mt. Roe $\left(\delta^{15} \mathrm{~N}=+7.3 \%\right.$ to $+15.8 \%$ o $)$ fall between those of the Hardey and Tumbiana formations (Thomazo et al., 2011; Stiueken et al., 2015b). The Tumbiana Formation has been noted for the highest nitrogen isotope ratios found to date in the rock record, with $\delta^{15} \mathrm{~N}$ values that extend up to 50\%o (Thomazo et al., 2011; Stuieken et al., 2015b), paired with unusually high ratios of organic carbon to total nitrogen (119-1719, Thomazo et al., 2011; Stiueken et al., 2015b). In the Mt Roe Formation, TOC/TN ratios (85-914) are also elevated compared to the Hardey and Bellary formations (5-271, Stuieken et al., 2015b, this study).

\subsection{Molybdenum isotopes and metal enrichments}


Molybdenum isotope data $\left(\delta^{98 / 95} \mathrm{Mo}\right)$ from sedimentary rocks of the Tumbiana Formation range from $-0.1 \%$ to $+1.8 \%$, with a mean of $0.4 \pm 0.4 \%$. This range is larger than that reported from the Mt. Roe and Hardey formations $(+0.2 \%$ to $+0.7 \%$, Wille et al., 2013). Molybdenum is not significantly enriched in any of the formations relative to modern average upper continental crust $\left(\mathrm{EF}_{\mathrm{Mo}}=2.5 \pm 1.5\right.$, with a few outliers with $\left.<1 \% \mathrm{Al}\right)$. Enrichments in other transition metals are similarly small or absent.

\subsection{Iron speciation}

Ratios of total iron to aluminum are elevated relative to average crust $(0.5$, Rudnick \& Gao, 2014) in the Tumbiana (0.7-3.7) and Kylena formations (0.9-2.9) and in some samples of the Mt. Roe Formation (0.03-0.9) - but not in the Hardey Formation (0.2-0.6). Ratios of highly reactive iron $\left(\mathrm{Fe}_{\mathrm{HR}}\right)$ to total iron $\left(\mathrm{Fe}_{\mathrm{T}}\right)$ fall mostly between 0.1 and 0.4 in the Tumbiana, Kylena and Mt. Roe formations; three samples in the Mt. Roe Formation are higher (up to 0.6). In the Hardey Formation, $\mathrm{Fe}_{\mathrm{HR}} / \mathrm{Fe}_{\mathrm{T}}$ falls mostly below 0.1. Ratios of pyrite-bound iron $\left(\mathrm{Fe}_{\mathrm{Py}}\right)$ to $\mathrm{Fe}_{\mathrm{HR}}$ range from 0 to 0.5 ; four samples of the Mt. Roe Formation plot between 0.6 and 0.9 .

\section{Interpretation}

The various proxies used in this study reveal distinct environmental and ecological properties in each depositional setting. Summaries of those patterns follow.

\subsection{Iron speciation}

The iron speciation proxy for paleoredox has been calibrated for marine environments with relatively low sedimentation rates (Raiswell \& Canfield, 1998; Anderson \& Raiswell, 2004). In marine and non-marine settings, however, high background rates of siliciclastic sedimentation in combination with relatively low abundances of reactive iron $\left(\mathrm{Fe}_{\mathrm{HR}}\right)$ may decrease the ratio of $\mathrm{Fe}_{\mathrm{HR}}$ to total iron $\left(\mathrm{Fe}_{\mathrm{T}}\right)$ and thus dilute potential enrichment patterns (e.g., Lyons \& Severmann, 2006). This possibility is particularly likely when the sediments are both mafic and tuffaceous, as in the Tumbiana, Kylena and Mt. Roe formations, because (a) mafic minerals are iron-rich, and (b) airfall tuff can be associated with rapid sedimentation rates. Furthermore, (c) the solubility of $\mathrm{Fe}^{2+}$ decreases markedly with increasing $\mathrm{pH}$ (Morgan \& Lahav, 2007). The mobility of reactive iron in lakes and rivers could thus be higher or lower compared to seawater, depending on $\mathrm{pH}$, which would also affect the $\mathrm{Fe}_{\mathrm{HR}} / \mathrm{Fe}_{\mathrm{T}}$ ratio irrespective of the redox state. For these three reasons, standard definitions of oxic, ferruginous and euxinic fields in terms of $\mathrm{Fe}_{\mathrm{Py}} / \mathrm{Fe}_{\mathrm{HR}}$ versus $\mathrm{Fe}_{\mathrm{HR}} / \mathrm{Fe}_{\mathrm{T}}$ crossplots (Fig. 5, e.g., Poulton \& Canfield, 2011) are therefore not necessarily applicable to nonmarine settings. Nevertheless, our iron data carry some environmental information about $\mathrm{pH}$ and sulfide availability.

\subsubsection{Tumbiana and Kylena formations}

The Tumbiana and Kylena formations have notably high $\mathrm{Fe}_{\mathrm{T}} / \mathrm{Al}$ ratios between 0.7 and 3.7 (mean $1.7 \pm 0.7$ ), consistent with abundant mafic tuff and basaltic sediment sources. Although iron-rich mafic minerals and tuff are generally susceptible to weathering, the $\mathrm{Fe}_{\mathrm{HR}} / \mathrm{Fe}_{\mathrm{T}}$ ratios of these samples are notably low (<0.3). It is unlikely that the lack of enrichment in $\mathrm{Fe}_{\mathrm{HR}} / \mathrm{Fe}_{\mathrm{T}}$ resulted from the lack of an appropriate carrier phase, because dissolved $\mathrm{Fe}^{2+}$, if present, could have been captured by the abundant carbonate. Furthermore, the Tumbiana lakes were at least partly closed basins with evidence of halite precipitation (Buick, 1992), making it unlikely that reactive $\mathrm{Fe}^{2+}$ was lost by fluvial export. The relative lack of $\mathrm{Fe}_{\mathrm{HR}}$ is thus consistent with suppressed iron 
solubility irrespective or redox under alkaline conditions in these lakes, as previously proposed (Stüeken et al., 2015b) (discussed below). Little ferrous iron would have been released into solution under such conditions. Instead it would have been retained in clays and zeolite minerals that formed during alteration of volcanic ash. This would explain the scarcity of authigenic iron minerals such as carbonates, oxides and sulfides.

\subsubsection{Hardey Formation}

High $\mathrm{pH}$ has not previously been invoked for the Hardey Formation, and we find no evidence for it in our data. Ratios of total iron to aluminum cluster tightly around a mean of $0.5 \pm$ 0.1 , equivalent to average upper continental crust $\left(0.5\right.$, Rudnick \& Gao, 2014). Ratios of Fe $\mathrm{HR}_{\mathrm{H}}$ to $\mathrm{Fe}_{\mathrm{T}}$ of $<0.2$ overlap with 'oxic' marine sediments that experienced minimal addition of authigenic iron (Poulton \& Raiswell, 2002). However, oxic conditions are incompatible with the record of detrital pyrite, uraninite and siderite in these sediments (Rasmussen \& Buick, 1999), unless the sedimentation rate was very high. It is perhaps more likely that detrital iron-silicate minerals diluted any authigenic iron minerals, and/or the formation of authigenic iron minerals was simply not favored in the absence of significant amounts of oxygen, carbonate or sulfide. It is therefore not possible to infer a redox setting for the Hardey Formation from the iron speciation data.

\subsubsection{Mt. Roe Formation}

In the Mt. Roe Formation, $\mathrm{Fe}_{\mathrm{T}} / \mathrm{Al}$ ratios vary between 0.03 and 0.91 , although given the mafic provenance we might predict values as high as those seen in the Tumbiana Formation. Paleosols in the Mt. Roe basalt have been noted for iron loss as a result of anoxic, acidic weathering (Macfarlane et al., 1994), and it is likely that clay particles in the lake deposits that we sampled were sourced from those exposed and leached horizons. Unlike the other units, the Mt. Roe Formation shows some $\mathrm{Fe}_{\mathrm{Py}} / \mathrm{Fe}_{\mathrm{HR}}$ ratios above 0.5, suggesting that sulfur was more readily available. Sulfate may have been supplied by localized oxidative weathering (Stüeken et al., 2012; Lalonde \& Konhauser, 2015) or by volcanic outgassing of $\mathrm{SO}_{2}$ and subsequent biological reduction. In the other formations, where $\mathrm{Fe}_{\mathrm{Py}} / \mathrm{Fe}_{\mathrm{HR}}$ ratios are generally lower (Fig. 5), sulfur input seems to have been relatively less.

In conclusion, the iron speciation data cannot resolve whether any of these fluvio-lacustrine water bodies in the Fortescue Group were oxic or anoxic because the iron-based proxies are presently limited in their relevance to non-marine environments. However, the low $\mathrm{Fe}_{\mathrm{HR}} / \mathrm{Fe}_{\mathrm{T}}$ ratios in the Tumbiana and Kylena formations are consistent with the interpretation of high $\mathrm{pH}$ in those settings (Stuieken et al., 2015b), and they indicate that none of these water bodies developed euxinia, as $\mathrm{Fe}_{\mathrm{Py}} / \mathrm{Fe}_{\mathrm{HR}}$ are mostly below 0.7 (Poulton \& Canfield, 2011). Slightly elevated $\mathrm{Fe}_{\mathrm{Py}} / \mathrm{Fe}_{\mathrm{HR}}$ ratios may indicate the presence of sulfide in some sedimentary pore waters.

\subsection{Trace elements and molybdenum isotopes}

The concentrations of trace elements appear to be primarily controlled by bedrock composition with no detectable overprint by redox processes or hydrothermal activity. Mild enrichments in $\mathrm{V}, \mathrm{Ni}$ and $\mathrm{Cr}(\mathrm{EF}>2)$ compared to average modern continental crust (Rudnick \& Gao, 2014), paired with mild depletions in $\mathrm{U}$ (mostly EF < 1), are consistent with a mafic sediment provenance and a generally more mafic Archean crust (Taylor \& McLennan, 1995). The absence of significant enrichments in $\mathrm{Cu}(\mathrm{EF} \sim 1-5), \mathrm{Zn}(\mathrm{EF} \sim 1-2)$ and $\mathrm{As}(\mathrm{EF} \sim 1-3)$ argues against input from hydrothermal fluids, either during or after deposition. Furthermore, the absence of marked 
depletions in first-row transition metals argues against metasomatic alteration, as observed in other geographic regions in the Fortescue Group (White et al., 2014a; White et al., 2014b).

High sedimentation rates, either through fluvial particle transport or rainout of volcanic ash, could easily have masked small elemental enrichments in the sediments. The molybdenum isotope record, however, appears to be more sensitive to Mo mobility than elemental abundances. The wide range of $\delta^{98 / 95}$ Mo values in the Tumbiana Formation ( $-0.1 \%$ o to $+1.8 \%$, Fig. 6) exceeds those of basalts $(-0.2 \%$ to $+0.3 \%$ ) and granites $(+0.1 \%$ to $+0.6 \%$ ) (Voegelin et al., 2014 , this study), which implies some degree of isotopic fractionation in the aqueous phase. The data thus strongly suggest that Mo was present in aqueous solution in the Tumbiana lakes. One possible source of dissolved Mo is alteration of volcanic glass, which can liberate Mo even in the absence of oxygen (Greaney et al., 2016). However, if this process were important, one would expect high levels of dissolved Mo and thus the potential for a wide range of fractionations in the Mt. Roe Formation where volcanic ash is abundant. This is not observed (Fig. 6). Thus, it is perhaps more likely that the Mo in the Tumbiana Formation was liberated by low levels of localized oxidative weathering (Stüeken et al., 2012; Lalonde \& Konhauser, 2015). Isotopic fractionations may have been induced as the dissolved Mo was partially sequestered into sulfide minerals (Poulson $e t$ al., 2006; Siebert et al., 2006; Neubert et al., 2008; Kendall et al., 2017) or assimilated into biomass (Zerkle et al., 2011). Regardless of the mechanism that fractionated the Mo isotopes, the isotopic range is evidence that Mo was present in solution, possibly as a result of mildly oxic conditions and consistent with claims of oxygenic photosynthesis based on the tufted mats and stromatolites in the Tumbiana Formation (Buick, 1992; Flannery \& Walter, 2012).

The comparatively small ranges of $\delta^{98 / 95}$ Mo in the Hardey Formation $(+0.4 \%$ to $+0.5 \%$ ) and Mt. Roe Formation $(+0.2 \%$ o to $+0.6 \%$ ) (Wille et al., 2013) may suggest that Mo was less mobile in these settings compared to the Tumbiana lakes; however, we cannot rule out that small amounts of authigenic, isotopically fractionated Mo precipitates were swamped by detrital Mo.

\subsection{Nitrogen fixation in the felsic sedimentary systems}

Total nitrogen and organic carbon are well correlated in our new samples from the Hardey Formation $\left(\mathrm{r}^{2}=0.8\right)$, suggesting that the nitrogen was derived from biomass. A similar though weaker trend $\left(r^{2}=0.4\right)$ was observed in previous analyses of outcrop samples from the Hardey and Bellary formations (Stüeken et al., 2015a). It is possible that these samples contain some fraction of detrital silicate-bound nitrogen. However, the tight $\mathrm{N}$ isotope range in both the Bellary and Hardey formations (Fig. 7) suggest that any potential isotopic effects from the admixture of a detrital $\mathrm{N}$ phase are minor. We can also rule out a significant metamorphic overprint, because such effects only become significant $(>1 \%$ ) for greenschist facies and above (reviewed by Thomazo $\&$ Papineau, 2013). Hence, the $\delta^{15} \mathrm{~N}$ values in these samples, falling around the atmospheric composition of $0 \%$, are most parsimoniously explained by biological $\mathrm{N}_{2}$ fixation using Mo-based nitrogenase (Stüeken et al., 2015a). The isotopic composition of biomass from organisms using this enzyme lies between $-2 \%$ and $+1 \%$ (reviewed by Casciotti, 2009), and 26 out of 30 data points from these two formations plot within this range. Alternative nitrogenases using Fe or $\mathrm{V}$ instead of Mo can be reasonably ruled out because they would produce larger fractionations between - $6 \%$ o and $-8 \%$ relative to the atmosphere (Zhang et al., 2014). Similarly, abiotic fixation products such as $\mathrm{HCN}$ from photochemistry or $\mathrm{NO}_{\mathrm{x}}$ from lightning would likely have been more fractionated (< -5\%, Ingerson, 1953; Moore, 1977; Kuga et al., 2014), and additional isotopic fractionation would have been imparted on such abiotic $\mathrm{NO}_{x}$ species during reduction to $\mathrm{N}_{2}$ or $\mathrm{NH}_{4}{ }^{+}$(McCready et al., 1983; Sigman et al., 2009). In short, the tight cluster of $\delta^{15} \mathrm{~N}$ values around a mean of $-0.6 \pm 1.0 \%$ o 
is inconsistent with secondary processing of a fractionated $\mathrm{NO}_{\mathrm{x}}$ reservoir and instead is best explained by a single dominant metabolism, in this case biological $\mathrm{N}_{2}$ fixation.

As noted above, Mo isotopes and concentrations in the Hardey Formation argue against a large Mo reservoir (Wille et al., 2013). At concentrations below 1-5 nM (100-20 times less than in the modern ocean), Mo can become limiting for modern nitrogen-fixing organisms (Fay \& de Vasconcelos, 1974; Attridge \& Rowell, 1997; Zerkle et al., 2006; Glass et al., 2010). In some modern lakes, Mo levels can be $<5 \mathrm{nM}$ and thus severely limit but not preclude biological productivity (Glass et al., 2012). It is conceivable, therefore, that ancient $\mathrm{N}_{2}$ fixers were adapted to low Mo concentrations through enzymatic pathways that enhanced the efficiency of Mo utilization (Glass et al., 2013).

\section{4. $\mathrm{NH}_{3}$ volatilization from alkaline lakes}

As noted previously (Thomazo et al., 2011; Stüeken et al., 2015b), the Tumbiana Formation stands out for its unusually high nitrogen isotope ratios of up to $+50 \%$ o (mean $+31 \pm$ 9\%o, 1 s.d., Fig. 7). The same is true for the Kylena Formation (up to $+30 \%$, mean $+24 \pm 7 \%$ ). These data are most reasonably interpreted as evidence for high $\mathrm{pH}(>9)$, which favors ${ }^{14} \mathrm{~N}$ loss via $\mathrm{NH}_{3}$ volatilization (Stïeken et al., 2015b). Aqueous $\mathrm{NH}_{4}{ }^{+}$released from dead biomass during degradation and diagenesis transforms into volatile $\mathrm{NH}_{3}$ with a $\mathrm{pKa}$ of 9.25 , and this process is associated with a fractionation of $45 \%$ at room temperature and 1 bar atmospheric pressure (Li et al., 2012). With a starting composition around $0 \%$ from $\mathrm{N}_{2}$ fixation and some degree of Rayleigh distillation, $\mathrm{NH}_{3}$ volatilization alone could have generated $\delta^{15} \mathrm{~N}$ values up to $+50 \%$. This interpretation is supported by the high $\mathrm{C} / \mathrm{N}$ ratios of these rocks $(458 \pm 326)$, despite their low metamorphic grade (Stüeken et al., 2015b). Such extreme $\mathrm{C} / \mathrm{N}$ ratios cannot be reconciled with a biological nitrogen removal process and instead require a post-mortem mechanism that preferentially removes $\mathrm{N}$ over $\mathrm{C}$. Hence the high $\delta^{15} \mathrm{~N}$ values and $\mathrm{C} / \mathrm{N}$ ratios were probably both consequences of alkaline $\mathrm{NH}_{3}$ devolatilization. It is possible that additional redox processes were operative in the Tumbiana lakes (Thomazo et al., 2011), as is the case in surface waters of modern alkaline lakes where $\mathrm{NH}_{3}$ builds up at depth and is released during seasonal water-column overturn (Jellison et al., 1993). If $\mathrm{NO}_{3}{ }^{-}$was a nitrogen source for some organisms, it could have elevated the average starting composition of biomass to $>0 \%$, as in the modern ocean. In such a case, values of up to $+50 \%$ o could then be explained with less extreme degrees of $\mathrm{NH}_{3}$ volatilization.

The Mt. Roe Formation, which is also mafic in its mineralogy but was probably hydrologically ephemeral (Rye \& Holland, 2000), is not as enriched in $\delta^{15} \mathrm{~N}$ (mean $+12 \pm 3 \%$ ) compared to the Kylena and Tumbiana formations, but it is similarly depleted in nitrogen $(\mathrm{C} / \mathrm{N}=$ $561 \pm 269$ ). The total spread in $\delta^{15} \mathrm{~N}$ over $9 \%$ (from $+7 \%$ o to $+16 \%$ ) is much wider than the range observed for the Bellary and Hardey formations and consistent with some form of secondary processing of nitrogen in the environment. In the modern ocean, for example, $\delta^{15} \mathrm{~N}$ values of up to $+15 \%$ can be generated by partial denitrification of $\mathrm{NO}_{3}{ }^{-}$to $\mathrm{N}_{2}$ and uptake of the residual heavy nitrate (Sigman et al., 2009; Tesdal et al., 2013), but in the absence of significant Mo isotope fractionations (Wille et al., 2013) or stromatolitic indications of $\mathrm{O}_{2}$ production, we see no evidence suggesting appreciable $\mathrm{NO}_{3}{ }^{-}$production. It is thus likely that $\mathrm{N}$ loss and associated isotopic fractionation were caused by $\mathrm{NH}_{3}$ volatilization from alkaline waters, similar to the Tumbiana Formation. The reason for the disparity between the Mt. Roe and Tumbiana formations could be a higher degree of redox cycling in oxic surface waters of the Tumbiana lakes, which, as noted above, may have elevated the $\delta^{15} \mathrm{~N}$ starting composition of biomass. Furthermore, differences in water depth could affect the overall degree of $\mathrm{N}$ loss from a system. In the relatively ephemeral 
system of the Mt Roe, where high $\mathrm{pH}$ conditions perhaps only developed transiently in sedimentary pore waters in contact with tuffaceous material, $\mathrm{NH}_{3}$ loss may be relatively less severe compared to long-lived evaporitic settings.

Claims of alkaline conditions in the Tumbiana, Kylena and Mt. Roe formations are consistent with the mafic substrate. Volcanic glass, in particular basaltic glass, is known to act as a strong base that consumes $\mathrm{H}^{+}$and releases cations into solution during aqueous alteration (Gislason \& Eugster, 1987; Gysi \& Stefansson, 2008). Modern alkaline lakes are therefore commonly associated with areas of active volcanism, such as the East African Rift (Cerling, 1994; Kempe \& Kazmierczak, 2011).

A previous interpretation of high $\mathrm{pH}$ in the Tumbiana lakes (Stuieken et al., 2015b) was recently contested by Hahn et al. (2015) based on rare earth element (REE) patterns. Modern alkaline lake waters can be highly depleted in light (LREE) over heavy REE, with (Pr/Yb) PAAs < 0.01 (Moeller \& Bau, 1993), and it was argued that similar depletions should be observed in carbonate precipitates (Hahn et al., 2015). However, there are no known examples of chemical sediments from bona fide alkaline lakes that capture the extreme LREE depletion seen in the water column. For example, cherts from modern alkaline Lake Magadi $\left((\mathrm{Pr} / \mathrm{Yb})_{\mathrm{PAAS}}=0.1-0.7\right)($ Kerrich et al., 2002) and carbonates from alkaline Lake Abhé ((Pr/Yb)PAAS $=0.2-1.5)$ (Dekov et al., 2014) have REE patterns that are significantly flatter than those from alkaline waters, and the REE pattern of one carbonate sample from the Green River Formation $((\mathrm{Pr} / \mathrm{Yb})$ PAAS $=0.7)$, a well-known Eocene alkaline lake, falls within the range of Tumbiana carbonates $\left((\mathrm{Pr} / \mathrm{Yb})_{\mathrm{PAAS}}=0.4-1.5\right)$ (Bolhar \& van Kranendonk, 2007; Coffey et al., 2013). Hence REE patterns may not be a straightforward proxy for alkaline conditions in the rock record.

Another argument against high $\mathrm{pH}$ has been raised based on a relatively small spread of $\delta^{44 / 40} \mathrm{Ca}$ values in Tumbiana carbonates compared to waters of modern alkaline Mono Lake (Blättler et al., 2017), where high $\left[\mathrm{HCO}_{3}{ }^{-}\right] /\left[\mathrm{Ca}^{2+}\right]$ ratios induce a Rayleigh effect during carbonate precipitation, leading to a larger spread in $\delta^{44 / 40} \mathrm{Ca}$ (Nielsen \& DePaolo, 2013). However, the calcium cycle in Mono Lake is not comparable to the Tumbiana Formation for several reasons. First, $\mathrm{Ca}^{2+}$ in Mono Lake is sourced primarily from small rivers and local springs with variable isotopic composition (Nielsen \& DePaolo, 2013), whereas in the Tumbiana Formation, $\mathrm{Ca}^{2+}$ would most likely have been leached from airfall tuff during intra-basinal water-rock interactions. Fluvial deposits are rare in the Tumbiana Formation, and spring deposits are absent, whereas tuff is ubiquitous and abundant (Buick, 1992). Hence $\mathrm{Ca}^{2+}$ recharge was likely more uniform in spatial extent and isotopic composition compared to Mono Lake. Possible differences in reservoir size could also play an important role. Second, waters of Mono Lake are enriched in phosphate compared to modern seawater by more than a factor of 20, which inhibits the precipitation of $\mathrm{CaCO}_{3}$ and imparts strong kinetic effects on Ca isotope fractionations (Nielsen \& DePaolo, 2013). It is unlikely that dissolved phosphate concentrations were similarly high in the Tumbiana lakes, because our samples show $\mathrm{P} / \mathrm{Al}$ ratios $(\mathrm{P} / \mathrm{Al} * 1000=14.1 \pm 5.8, \mathrm{n}=61$, unpublished data) that are only about twice as high as in Neoarchean marine shales $(\mathrm{P} / \mathrm{Al} * 1000=6.7 \pm 5.8, \mathrm{n}=41$, Yamaguchi, 2002) and average continental crust $(\mathrm{P} / \mathrm{Al} * 1000=8$, Rudnick \& Gao, 2014). Hence, Mono Lake is not a suitable analog for the Tumbiana Formation in terms of Ca chemistry. Most importantly, carbonate precipitates in Mono Lake actually show a very narrow spread in $\delta^{44 / 40} \mathrm{Ca}-$ much narrower than the isotopic spread in dissolved Ca (Nielsen \& DePaolo, 2013) and roughly identical to that reported from Tumbiana carbonates (Blättler et al., 2017). Hence, carbonates may simply not capture the Rayleigh effect observed in the aqueous phase, which makes the $\delta^{44 / 40} \mathrm{Ca}$ proxy problematic for tracking alkalinity in deep time. 


\subsection{Carbon cycling}

The Neoarchean (2.8-2.5 Ga) was a time of exceptionally light organic carbon isotope ratios (Krissansen-Totton et al., 2015). Marine sediments commonly fall between $-30 \%$ o to $-45 \%$ compared to a range of $-20 \%$ to $-30 \%$ for the remainder of Earth history. This pattern of extreme ${ }^{13} \mathrm{C}$ depletion is usually attributed to widespread production of isotopically light methane that was partially reincorporated into biomass via methanotrophy (Hayes, 1994; Hinrichs, 2002; Eigenbrode \& Freeman, 2006; Fischer et al., 2009; Czaja et al., 2010; Zerkle et al., 2012; Izon et al., 2015). Slotznick \& Fischer (2016) recently proposed that light organic $\delta^{13} \mathrm{C}$ values in the Tumbiana Formation were instead the result of acetogenesis and reassimilation of light acetate, which would not necessitate any oxidant, unlike methanotrophy. We will revisit this hypothesis below.

\subsubsection{Preservation of carbon isotope signatures}

As noted above, nitrogen isotope ratios in the three mafic settings in the Fortescue Group have likely been affected by $\mathrm{NH}_{3}$ loss under alkaline conditions. There are no known effects of high $\mathrm{pH}$ on carbon isotopes. In general, diagenesis can lower organic $\delta^{13} \mathrm{C}$ values by $1-2 \%$ through selective preservation of heavier compounds (Lehman et al., 2002) and even more so through the addition of isotopically light biomass from methanogenic and methanotrophic organisms. The latter can be significant in samples where $\delta^{13} \mathrm{C}_{\text {org }}$ is less than $-35 \%$ and will be further discussed below.

Metamorphic alteration can lead to a re-equilibration between organic matter and carbonate such that $\delta^{13} \mathrm{C}_{\text {org }}$ increases while $\delta^{13} \mathrm{C}_{\text {carb }}$ decreases. However, this effect is minor $(<3 \%)$ below greenschist facies metamorphism (McKirdy \& Powell, 1974; Hoefs \& Frey, 1976; Hayes et al., 1983; Schidlowski, 1987). Furthermore, as noted above (Fig. 4), we tend to observe light $\delta^{13} \mathrm{C}_{\text {carb }}$ values in Tumbiana samples with light $\delta^{13} \mathrm{C}_{\text {org }}$, which is opposite to the expected metamorphic trend and more likely an artifact of diagenesis. In these samples, amount of carbonate-bound carbon is in nearly all cases at least equal or greater than the amount of organic-bound carbon. If the observed trend were the result of metamorphic overprinting rather than diagenesis, then organic $\delta^{13} \mathrm{C}_{\text {org }}$ should be more positive in samples with light $\delta^{13} \mathrm{C}_{\text {carb }}$, which is not observed. A significant degree of metamorphic alteration of primary signals is therefore unlikely.

\subsubsection{The Calvin cycle and oxygenic phototrophy in the Tumbiana Formation}

The organic carbon isotope data from the Hardey and Bellary formations (mean - $38.7 \pm$ 4.2\%o) (Fig. 7) fall within the Neoarchean marine range, whereas the Tumbiana, Kylena and Mt. Roe formations (mean $-45.9 \pm 7.8 \%$ ) are systematically lighter. Values heavier than $-35 \%$ may be explained by primary production through the Calvin-Benson-Bassham (or reductive pentose phosphate) cycle (-15\% to $-35 \%$, Schidlowski, 1987; Zerkle et al., 2005). This pathway is used by a range of organisms, including cyanobacteria, some anoxygenic phototrophs and some chemotrophs, and it may have been the dominant mode of $\mathrm{CO}_{2}$ fixation over most of Earth history (Nisbet et al., 2007). In the case of the Tumbiana and Kylena formations, the presence of stromatolites, the distinctive morphology of the tufted mats and the inferred scarcity of ferrous iron and sulfide as electron donors for anoxygenic phototrophs have been used to suggest that cyanobacterial productivity was at least in part responsible for primary production (Buick, 1992; Flannery \& Walter, 2012). The most parsimonious explanation for the heavier organic $\delta^{13} \mathrm{C}$ values as high as $-15 \%$ may thus be a cyanobacterial contribution. In the Hardey, Bellary and Mt. Roe 
formations, by contrast, the Calvin cycle was probably not a dominant mode of productivity, because $\delta^{13} \mathrm{C}_{\text {org }}$ values heavier than $-35 \%$ are rare at these sites.

\subsubsection{Autotrophic methanogenesis in the Hardey and Bellary formations}

Organic carbon isotope values down to around $-42 \%$ could reflect $\mathrm{CO}_{2}$ fixation by the acetyl-CoA pathway, which is used by many anaerobic organisms, including autotrophic methanogens, acetogens and some sulfate reducers (Schidlowski, 1987; Zerkle et al., 2005). Values significantly lighter than $-42 \%$ are incompatible with any known $\mathrm{CO}_{2}$ fixation pathway that uses atmospheric $\mathrm{CO}_{2}$ with a composition of -7\%o (Schidlowski, 1987; Zerkle et al., 2005) and could instead reflect incorporation of isotopically light $\mathrm{CH}_{4}$ into biomass (Hayes, 1994; Hinrichs, 2002; Eigenbrode \& Freeman, 2006). Two alternatives to autotrophic methanogenesis, acetogenesis and methanotrophy for $\delta^{13} \mathrm{C}_{\text {org }}$ values below $-35 \%$ are possible, but not likely for the Hardey and Bellary formations. First, such light values could have resulted from $\mathrm{CO}_{2}$ fixation by the Calvin cycle, if the $\mathrm{CO}_{2}$ source was lighter than atmospheric $\mathrm{CO}_{2}$. However, open fluviolacustrine settings such as the Hardey and Bellary were likely equilibrated with the $\mathrm{CO}_{2}$-rich Archean atmosphere through dynamic mixing, as is true today (Mook, 2001). Atmospheric $\mathrm{CO}_{2}$ is set to a value of $-7 \%$ today because it is buffered by the much larger marine DIC pool through an equilibrium fractionation of roughly 7-8\% between gaseous $\mathrm{CO}_{2}$ and aqueous $\mathrm{HCO}_{3}{ }^{-}$(Hayes et $a l ., 1999)$. The carbon isotope composition of the Neoarchean atmosphere would probably have been about the same as today, as suggested by the nearly stable $\delta^{13} \mathrm{C}_{\text {carb }}$ record through time in phases that capture marine DIC (Krissansen-Totton et al., 2015).

The second alternative possibility to autotrophic methanogenesis, acetogenesis and methanotrophy is heterotrophic methanogenesis using isotopically light organic substrates for conversion to methane and biomass (Londry et al., 2008). The biomass of such heterotrophic methanogens can be up to $30 \%$ depleted compared to their carbon source (Londry et al., 2008) and could thus explain organic carbon isotope values down to $-60 \%$ if the starting substrate were produced by the Calvin cycle or another $\mathrm{CO}_{2}$ fixation pathway. However, we would expect that a signature of those organisms would result in a wide spread of $\delta^{13} \mathrm{C}_{\mathrm{org}}$, ranging from the composition of the primary producers to that of the heterotrophic consumers. In the Hardey and Bellary formations, the strong mode around $-40 \%$ (minimum $-42.5 \%$, Fig. 7 ) suggests that a single process was dominant and is thus inconsistent with heterotrophic methanogenesis.

We are left with autotrophic methanogenesis, acetogenesis (the acetyl-CoA carbon fixation pathway) and methanotrophy. Methanotrophy was probably insignificant for lack of an oxidant. The scarcity of pyrite in these sediments suggests that sulfate reducers were minor, and as noted above, the presence of redox-sensitive detrital minerals, the scarcity of $\delta^{13} \mathrm{C}_{\text {org }}$ values within the range of cyanobacteria, as well as the nitrogen isotope data argue against appreciable $\mathrm{O}_{2}$. Collectively, these observations suggest that methanotrophy was not a major metabolisms in the Hardey and Bellary settings. Hence, autotrophic methanogenesis and/or acetogenesis using atmospheric $\mathrm{H}_{2}$ and $\mathrm{CO}_{2}$ are perhaps the most plausible metabolisms in these fluvio-lacustrine settings. Importantly, autotrophic methanogens require a minimum atmospheric $\mathrm{H}_{2}$ mixing ratio of around $40 \mathrm{ppm}$ (Kral et al., 1998), which is at the bottom end of values inferred from climate models of the Archean (e.g. Kharecha et al., 2005; Claire et al., 2014) and may provide a useful lower limit.

\subsubsection{Methanotrophy in the Tumbiana, Kylena and Mt. Roe formations}


The light but highly variable $\delta^{13} \mathrm{C}_{\text {org }}$ data from the more mafic Tumbiana, Kylena and Mt. Roe formations imply some contribution from either heterotrophic methanogenesis or some form of methane or acetate assimilation. Slotznick \& Fischer (2016) tried to rule out methanotrophy in the Tumbiana Formation on the basis of inorganic $\delta^{13} \mathrm{C}_{\text {carb }}$ data from stromatolites. Methanotrophy generates isotopically light $\mathrm{CO}_{2}$, which mixes with other dissolved inorganic carbon (DIC) and can lead to isotopically light carbonate precipitates. The two stromatolites analyzed by Slotznick $\&$ Fischer (2016) showed a tight cluster of $\delta^{13} \mathrm{C}_{\text {carb }}$ from $-1 \%$ to $+1 \%$, which they argued was inconsistent with methanotrophic $\mathrm{CO}_{2}$ production. However, a compilation of $150 \delta^{13} \mathrm{C}_{\text {carb }}$ data points for the Tumbiana from our study and previous investigations (Thomazo et al., 2009; Coffey et al., 2013) shows a wide range of $\delta^{13} \mathrm{C}_{\text {carb }}$ values from $-9.2 \%$ to $+1.9 \%$, with a mean of $-0.8 \pm$ $2.0 \%$ (Fig. 4a). In the Kylena Formation, $\delta^{13} \mathrm{C}_{\text {carb }}$ values range from $-5.7 \%$ o to $+2.1 \%$ (mean +0.1 $\pm 2.2 \%$, $\mathrm{n}=19$, Flannery et al., 2014, this study). The more negative values tend to occur in samples with less than $40 \%$ carbonate and are plausibly explained by mixing of methanotrophic $\mathrm{CO}_{2}$ with a larger dissolved DIC reservoir. As discussed above, the Tumbiana lakes may have been alkaline with a $\mathrm{pH}>9$, and hence DIC levels may have exceeded $1000 \mathrm{mM}$ - using the framework of Slotznick \& Fischer (2016, their Fig. 4a). At such high DIC concentrations, a contribution of isotopically light $\mathrm{CO}_{2}$ to DIC via methanotrophy would be strongly diluted. Figure $4 \mathrm{~b}$ of Slotznick \& Fischer (2016) suggests the expected $\delta^{13} \mathrm{C}_{\text {carb }}$ values at high $\mathrm{pH}$ would be heavier than $-2.5 \%$, making a methanotrophic contribution difficult to detect - except from samples with lower carbonate abundances where the methanotrophic signature becomes more obvious (Fig. 4a). Acetate-based anaerobic metabolisms may still have been present, but the occurrence of numerous light $\delta^{13} \mathrm{C}_{\text {carb }}$ values supports previous arguments for methanotrophy during deposition of the Tumbiana and Kylena formations (Hayes, 1994; Hinrichs, 2002; Eigenbrode \& Freeman, 2006). Light $\delta^{13} \mathrm{C}_{\text {carb }}$ values paired with light $\delta^{13} \mathrm{C}_{\text {org }}$ values also argue against heterotrophic methanogenesis as the sole cause of the light $\delta^{13} \mathrm{C}_{\text {org }}$ data, because that metabolism does not generate isotopically light $\mathrm{CO}_{2}$ or $\mathrm{HCO}_{3}{ }^{-}$.

\subsubsection{Variable electron acceptors for methanotrophs}

The likelihood of methanotrophy leaves open the question of which substrate was used as an electron acceptor for the oxidation of methane. We suspect that both aerobic and anaerobic processes may have played a role. In the Mt. Roe Formation, the moderate amounts of pyrite (Fig. 5) may be a result of sulfate reduction, which can be coupled to methane oxidation even at low sulfate concentrations (Beal et al., 2011). We see no evidence of $\mathrm{O}_{2}$ production in the Mt. Roe Formation, which would also rule out nitrate as an electron acceptor. There is no evidence for extensive iron redox cycling in any of these non-marine settings, which is also supported by iron isotope data (Czaja et al., 2010). Hence, sulfate would be the most plausible oxidant for methane oxidation in the Mt. Roe Formation. In the Tumbiana and Kylena formations, where stromatolites (likely cyanobacterial) are common and sulfide minerals scarce (Buick, 1992, this study), aerobic methanotrophy is likely to have played a more important role. However, small but significant fractionations in sulfur isotopes suggest that some microbial sulfate reduction also occurred at this

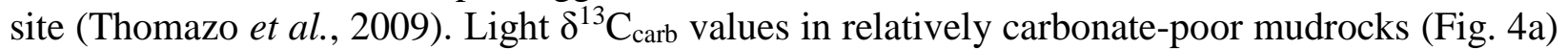
are consistent with a diagenetic process that oxidized methane below the oxic surface layer of the Tumbiana lakes (i.e., sulfate reduction linked to anaerobic oxidation of methane). We therefore favor a combination of aerobic and anaerobic metabolisms for methanotrophy.

\section{Environmental patterns}


In summary, our data reveal patterns in microbial metabolism in the Fortescue Group that appear to have been driven by physicochemical characteristics of the environments (Fig. 8, Table 1), consistent with studies of modern microbial biogeography (Martiny et al., 2006). The more felsic Hardey and Bellary formations were deposited in open fluvio-lacustrine settings hosted $\mathrm{N}_{2-}$ fixers and perhaps autotrophic methanogens using atmospheric $\mathrm{H}_{2}$ and $\mathrm{CO}_{2}$, but we see no clear evidence for photosynthetic activity, sulfate reduction or methanotrophy. These metabolisms may have been present at low levels, but the tightly clustered $\delta^{13} \mathrm{C}_{\text {org }}$ data around $-40 \%$ suggest that they were not producing significant amounts of biomass. Nitrogen isotopes are consistent with nitrogen-limited conditions and molybdenum-based fixation of atmospheric $\mathrm{N}_{2}$. In the mafic, evaporitic Tumbiana and Kylena formations, which represent closed systems, our iron-speciation data suggest that ferrous iron was insoluble and that sulfide was not abundant. This conclusion supports the inference of alkaline conditions (Stüeken et al., 2015b). It also supports the interpretation that the abundant stromatolites in these stratigraphic units were built by oxygenic phototrophs, because alternative electron donors other than $\mathrm{H}_{2} \mathrm{O}$ were scarce (Buick, 1992). The light $\delta^{13} \mathrm{C}_{\text {org }}$ values down to $-57 \%$ are most likely the result of methanotrophy, using a combination of $\mathrm{O}_{2}$ and $\mathrm{SO}_{4}{ }^{2-}$ as oxidants. This conclusion is supported by light $\delta^{13} \mathrm{C}_{\text {carb values ranging down to }}$ -9\%o (cf. Slotznick \& Fischer, 2016) and slightly fractionated sulfur isotopes in pyrite (Thomazo et al., 2009). In the mafic but shallower ephemeral ponds of the Mt. Roe Formation, similarly light $\delta^{13} \mathrm{C}_{\text {org }}$ values are also interpreted as evidence of methanotrophy, but in this case we have seen no indication of photosynthetic activity that could have provided $\mathrm{O}_{2}$. Instead, $\mathrm{SO}_{4}{ }^{2-}$ may have been the dominant oxidant of $\mathrm{CH}_{4}$, as indicated by the moderate amounts of pyrite in some of our Mt. Roe samples.

Overall, methanotrophy appears to have been favored in mafic systems, and oxygenic photosynthetic activity was favored in long-lived evaporitic mafic systems that evolved to alkaline conditions (Fig. 8). Importantly, modern cyanobacteria are most productive and diverse in alkaline lakes relative to other lakes and the open ocean (Zavarzin, 1993), and hence mafic volcanic terrains on Archean continents may have been ideal habitats for them to thrive. We speculate that the propensity for methanotrophy in mafic environments may be related to a higher supply of oxidants in the form of biogenic $\mathrm{O}_{2}$ from thriving cyanobacterial colonies and/or biogenic or volcanogenic $\mathrm{SO}_{4}{ }^{2-}$.

\section{Ecological and evolutionary implications}

Our results support the idea that environmental diversity on the Archean Earth fostered microbial diversity. A range of microbial metabolisms along environmental gradients has previously been described from marine environments of Archean and Proterozoic age (e.g. Eigenbrode \& Freeman, 2006; Tice \& Lowe, 2006; Guy et al., 2012; Stüeken, 2013; Luo et al., 2014; Koehler et al., 2017). In those marine settings, environmental gradation is usually ascribed to differing redox settings between shallow and deep habitats. Our data suggest that biological diversity was at least partly controlled by geological processes such as volcanism and sediment composition and partly by geographical and hydrological parameters. Such environmental controls are commonly seen today in studies of microbial biogeography (Martiny et al., 2006), but they have not previously been recognized in ancient microbial ecosystems. By analogy to the extreme diversification seen in macroscopic multicellular eukaryotes in terrestrial environments (Little, 1990; Kenrick \& Crane, 1997), it is conceivable that geological, geographical and hydrological factors such as those described here contributed to the evolution of early life, in addition to stochastic biological mutations and innovations. Varying physico-chemical conditions like those 
manifest across the Fortescue water bodies could well have acted as drivers for biochemical evolution in earlier times by emphasizing different metabolic substrates at differing bioavailabilities in distinct habitats.

\section{Acknowledgments}

Financial support for this study came from the NASA postdoctoral program (EES), the NSF-FESD program (RB, TWL), the NASA Astrobiology Institute (TWL, NJP, RB) and the NASA Exobiology program (grant NNX16AI37G to RB). We thank the Geological Survey of Western Australia for access to the core library and for assistance with sample collection. Christian Hallman (MPI Bremen) kindly provided two additional samples of ooids and lapilli stones from core ABDP-10. Andy Schauer (UW), Steve Bates (UCR), Andy Robinson (UCR) and Dan Asael (Yale) are thanked for technical support. We thank Sean Crowe and three anonymous reviewers for constructive comments that improved the manuscript. 


\section{Figure captions}

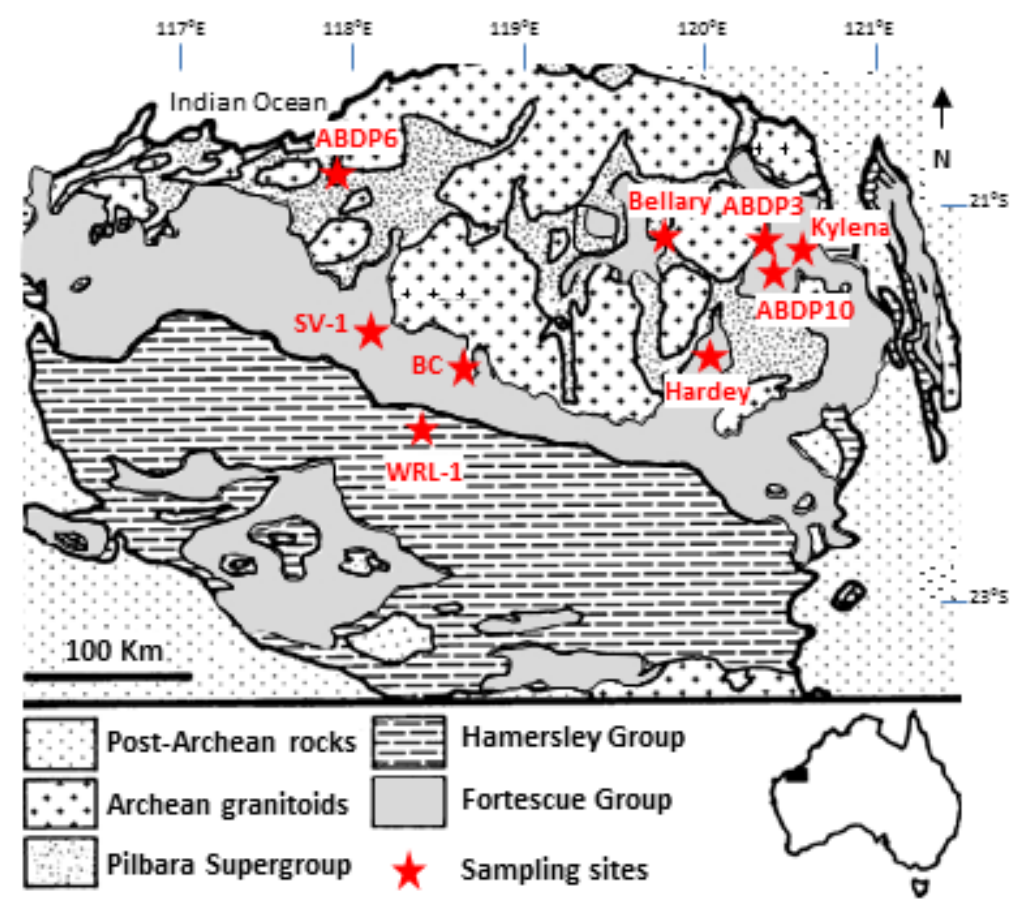

Figure 1: Geographic location of the Fortescue Group. The map was modified from Buick (1992). Red stars mark sampling sites for this and previous studies that produced data used in this manuscript. BC = Beabea Creek (Tumbiana). WRL-1 (Tumbiana), SV-1 (Tumbiana), ABDP-3 (Hardey), ABDP-6 (Mt. Roe) and ABDP-10 (Tumbiana) are drill cores. 


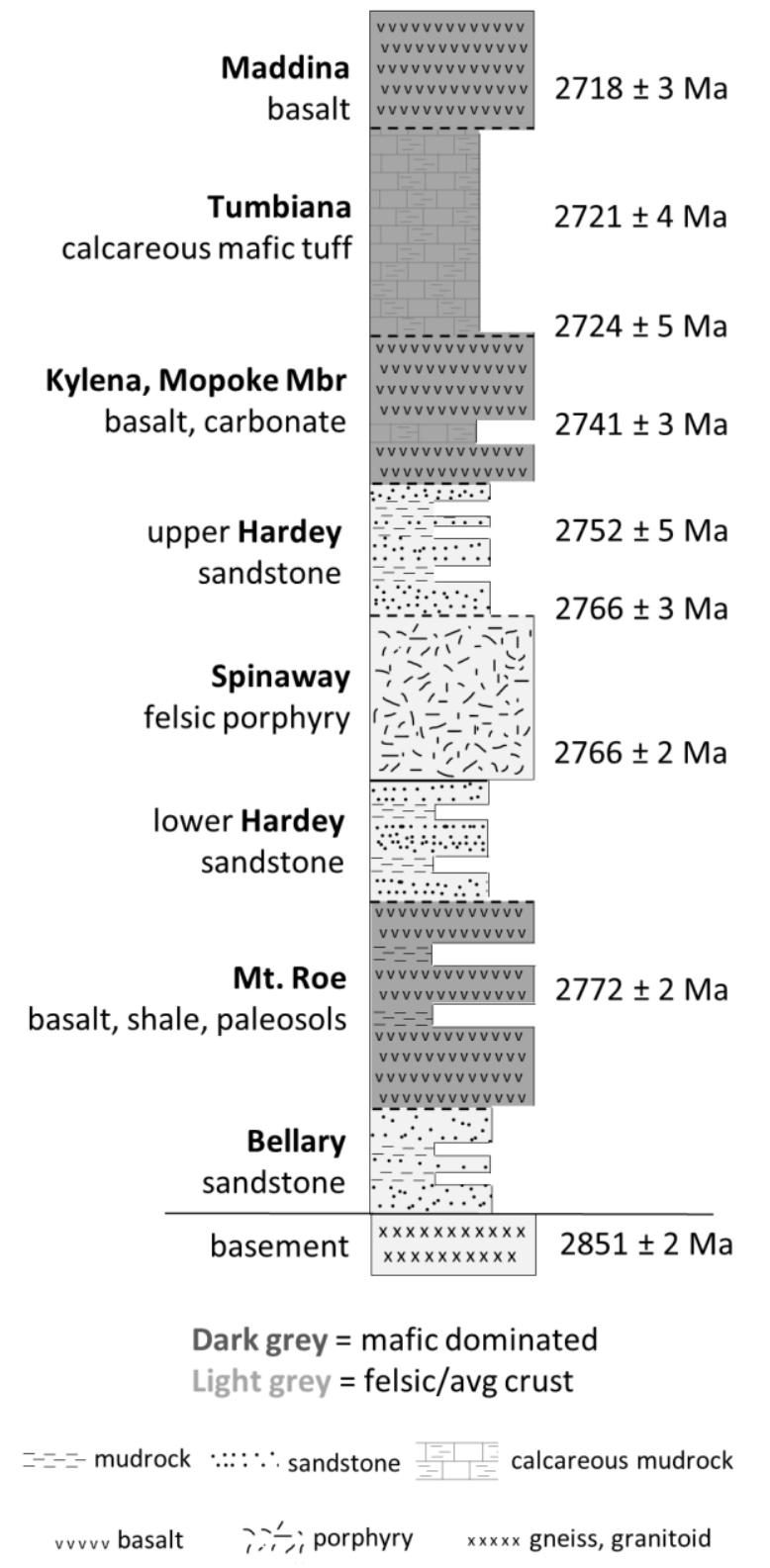

Figure 2: Stratigraphy of the Neoarchean Fortescue Group. The stratigraphic sequence and ages are adopted from Blake et al. 2004. 

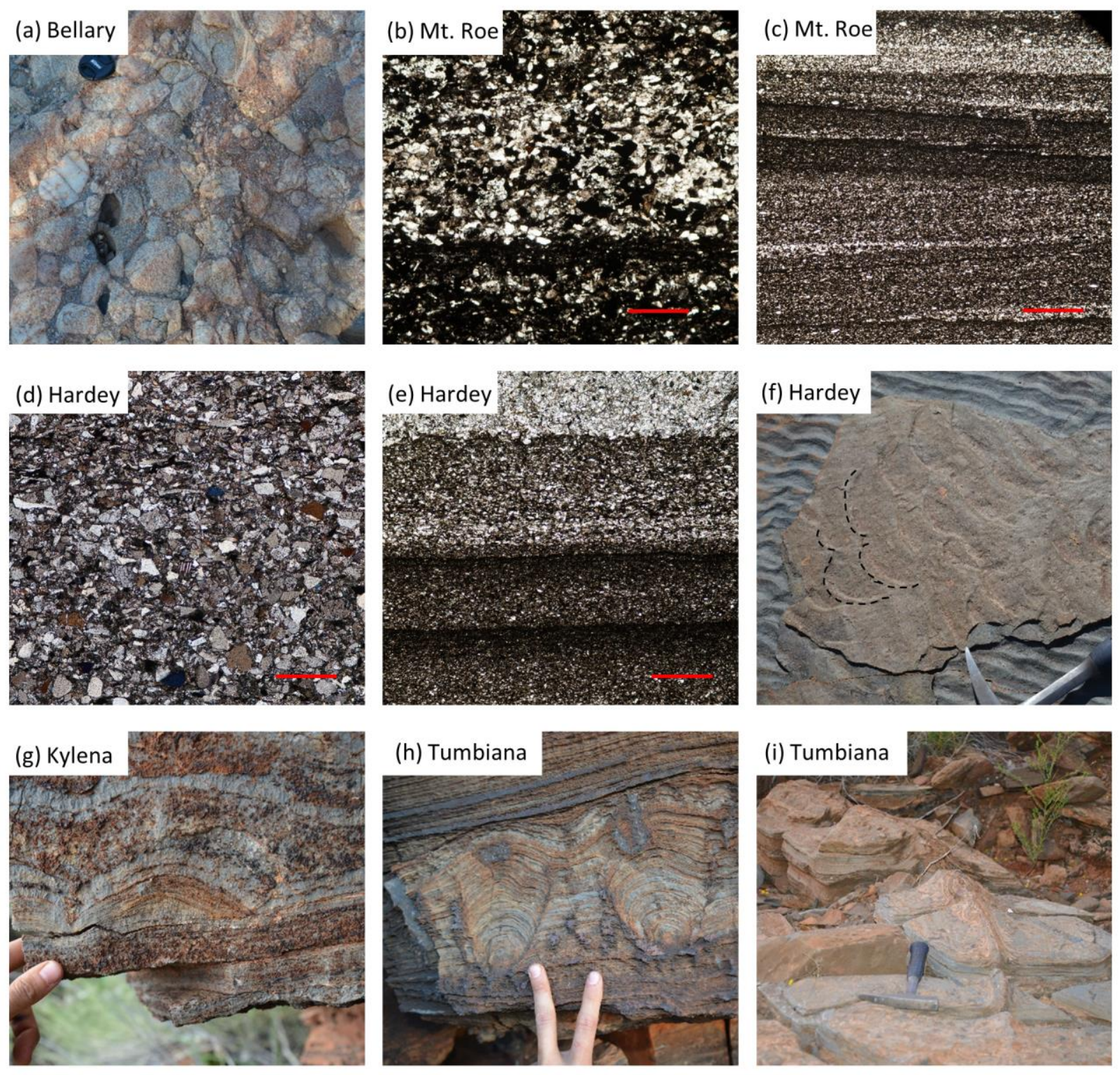

Figure 3: Field photos and photomicrographs. (a) Felsic conglomerate in the Bellary Formation. Lens cap in the top left corner is $\sim 7 \mathrm{~cm}$ wide. (b) Silt lamina in the Mt. Roe Formation. Opaque silt grains are devitrified mafic volcanic fragments. Scale bar $=0.3 \mathrm{~mm}$. (c) Graded lamination in shale of the Mt. Roe Formation. Scale bar $=0.3 \mathrm{~mm}$. (d) Silt to very fine sand lamina in the Hardey Formation, crossed polars. Grains are mostly quartz, feldspar and muscovite. Scale bar $=0.3 \mathrm{~mm}$. (e) Graded shale in the Hardey Formation. Scale bar $=0.3 \mathrm{~mm}$. (f) Wave ripples (lower surface) and current ripples (upper surface) in the Hardey Formation. Dashed lines on the upper surface mark catenary ripple crests. Width of hammer stem $\sim 4 \mathrm{~cm}$. (g) Stromatolitic carbonate in the Kylena Formation. (h) Stromatolites in the Tumbiana Formation. (i) Teepee structure in the Tumbiana Formation as evidence of desiccation. Hammer is $\sim 40 \mathrm{~cm}$. 

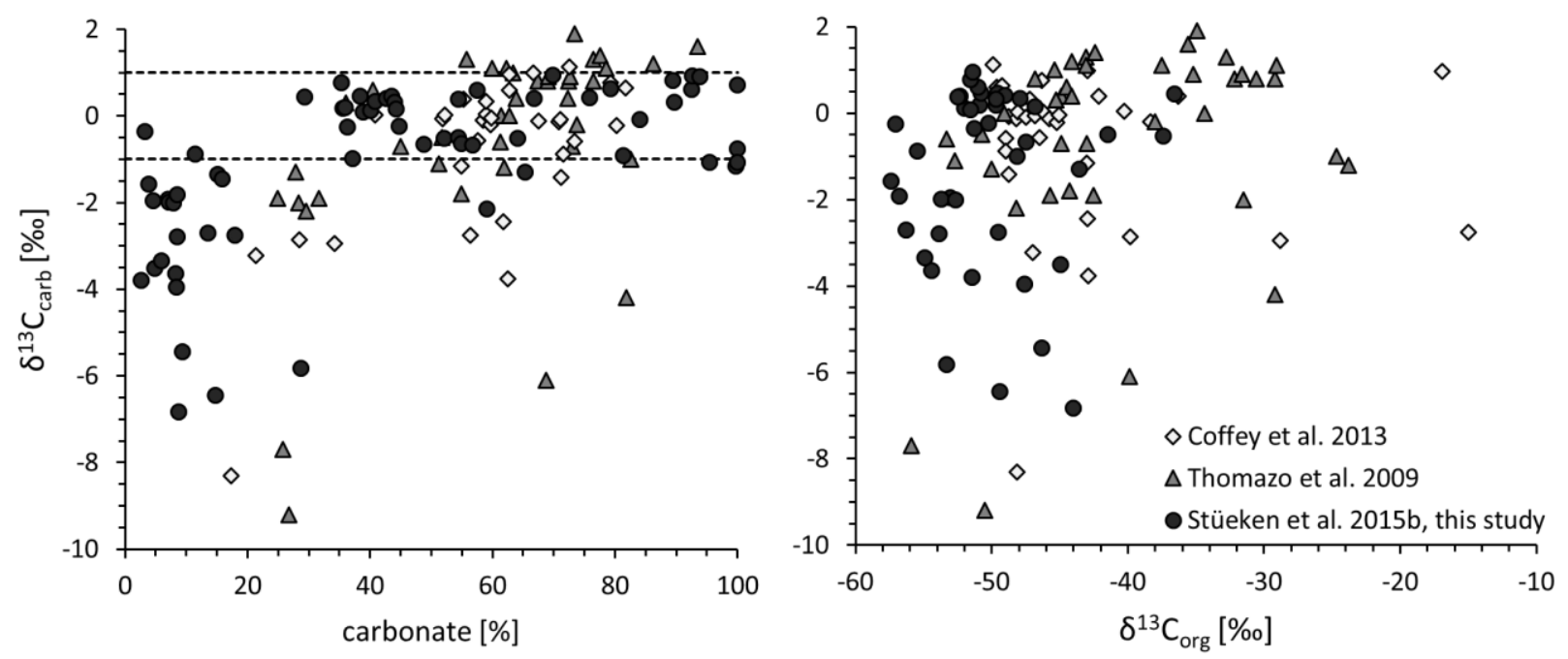

Figure 4: Carbon isotope trends in the Tumbiana Formation. (a) Inorganic carbon isotopes versus carbonate content. Dashed lines mark marine range (Eigenbrode \& Freeman, 2006). (b) inorganic versus organic carbon isotopes.

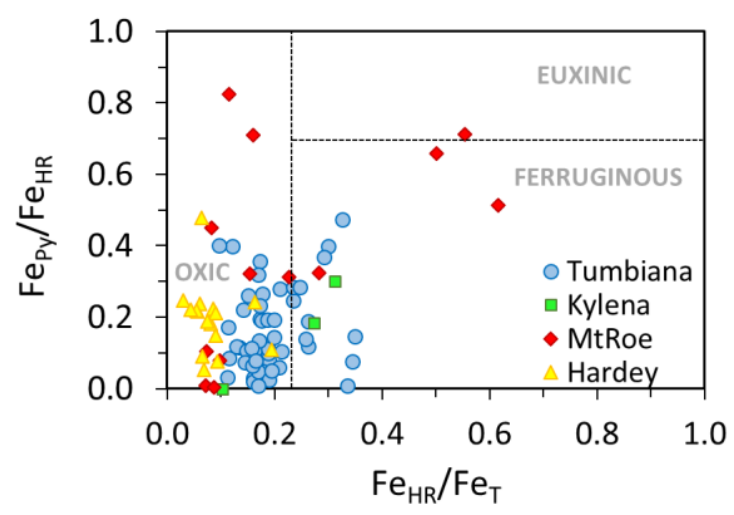

Figure 5: Iron speciation. Boundaries between oxic, ferruginous and euxinic conditions are taken from Poulton \& Canfield (2011) calibrated for marine sediments. The threshold between oxic and anoxic settings as inferred from $\mathrm{Fe}_{\mathrm{HR}} / \mathrm{Fe}_{\mathrm{T}}$ does not apply in lacustrine and fluvial settings, because this ratio can be affected by high sedimentation rates and $\mathrm{pH}$ effects on Fe solubility (see text). The threshold for euxinia based on $\mathrm{Fe}_{\mathrm{PY}} / \mathrm{Fe}_{\mathrm{HR}}$ remains valid. Our data thus indicate that none of these sites were euxinic, except for perhaps parts of the Mt Roe Formation.

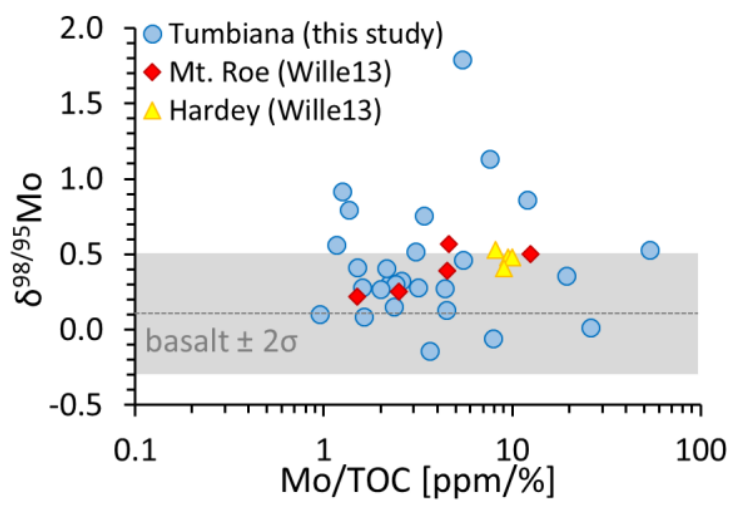


Figure 6: Molybdenum isotopes. Mt.Roe and Hardey data are taken from Wille et al. (2013). The basalt range is that of basalts underlying the Tumbiana Formation. It encompasses the range of modern basalts $(-0.2 \%$ to $+0.3 \%$, Voegelin et al., 2014). The wide range of values in sediments from the Tumbiana lakes indicates that Mo was mobile in this setting, possibly as a result of mildly oxic conditions proximal to cyanobacterial mats (Buick, 1992; Flannery \& Walter, 2012).

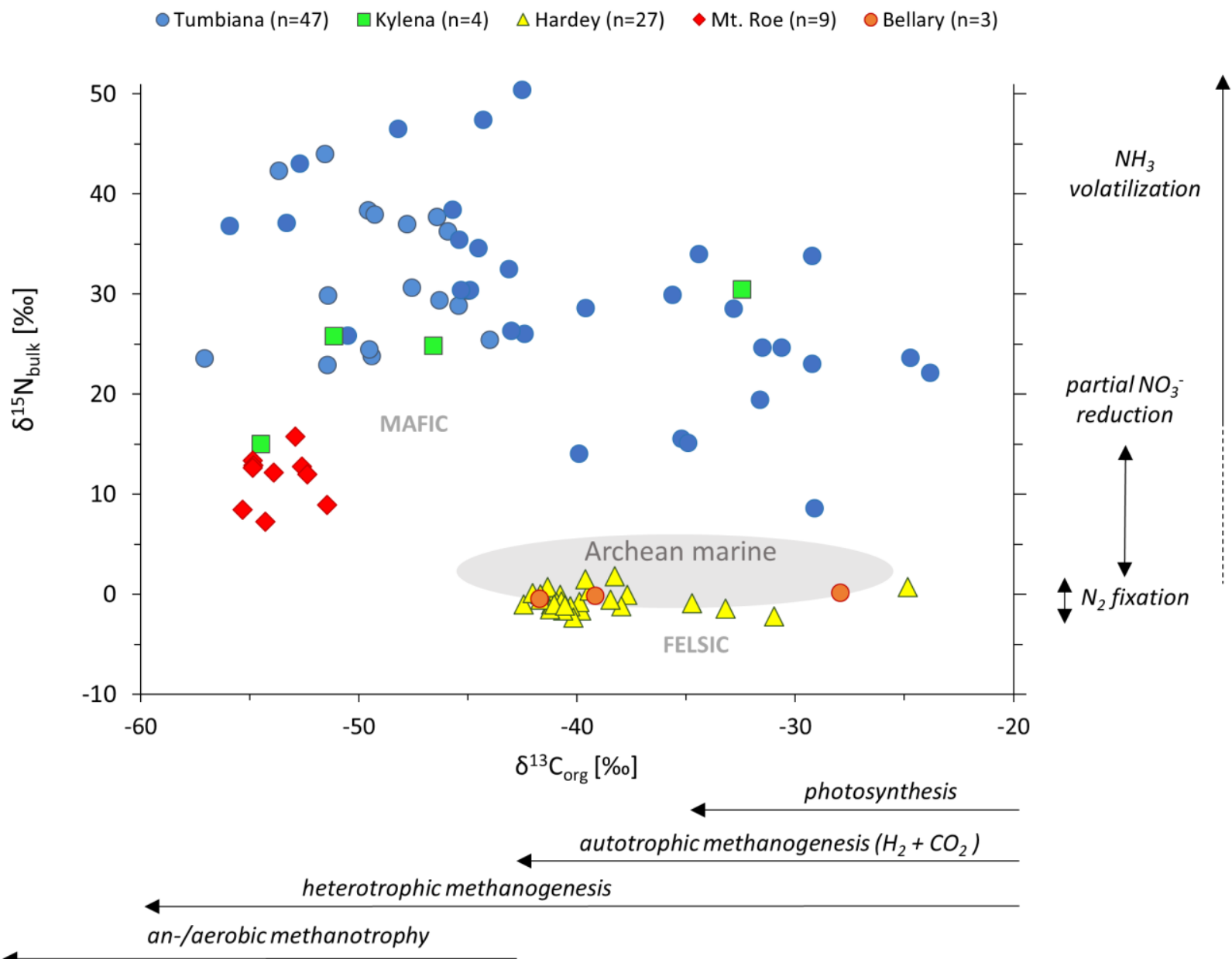

Figure 7: Carbon and nitrogen isotopes. The mafic settings show evidence of $\mathrm{NH}_{3}$ volatilization at high $\mathrm{pH}(>9)$, consistent with the development of alkaline conditions in modern volcanic terrains (Kempe \& Kazmierczak, 2011). The felsic settings are dominated by biological $\mathrm{N}_{2}$ fixation. Evidence of methanotrophy occurs in the mafic sites but not in the felsic environment. The heavier end of the $\delta^{13} \mathrm{C}_{\text {org }}$ spectrum in the Tumbiana Formation may reflect photosynthetic organisms as invoked by Buick (1992) and Flannery \& Walter (2012). All data from the Mt Roe Formation and most data from the Hardey Formation are from this study. Additional data are taken from Thomazo et al. (2011), Stüeken et al. (2015a) and Stüeken et al. (2015b). 


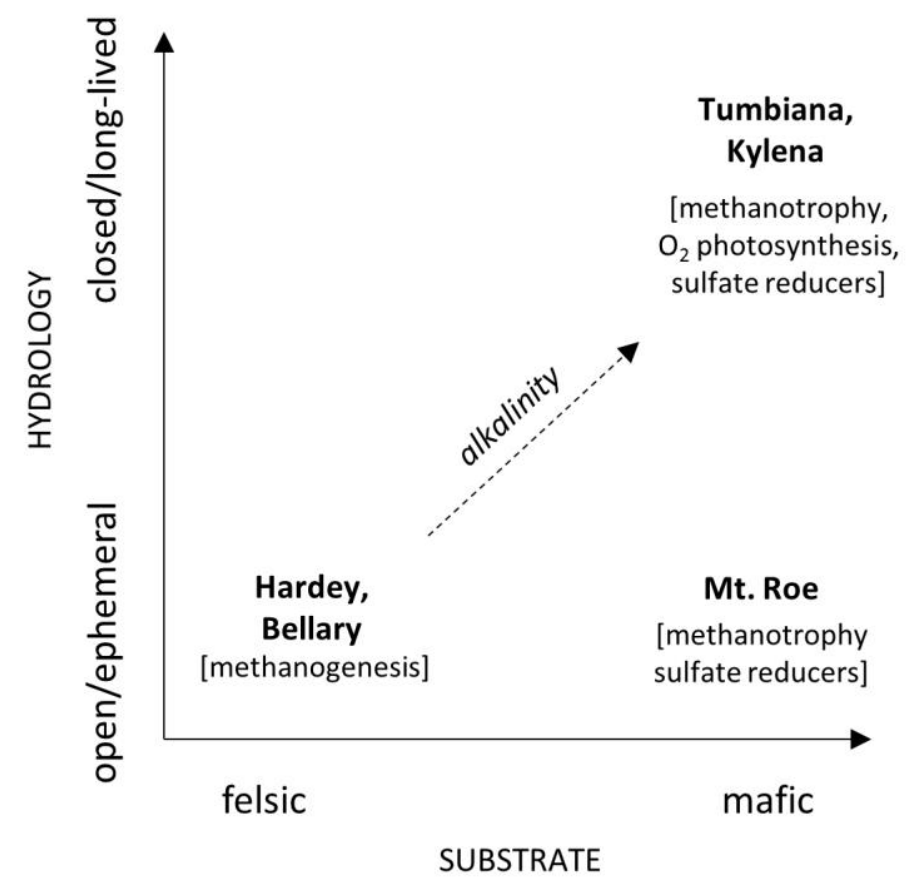

Figure 8: Environmental and metabolic patterns in the non-marine Fortescue Group. In the more felsic and hydrologically open settings (Bellary and Hardey formations), carbon isotopes suggest the presence of autotrophic methanogens. Other metabolisms were likely minor, if present. The mostly mafic and hydrologically open Mt Roe setting shows evidence of methanotrophy, possibly coupled to microbial sulfate reduction. The mafic and evaporitic Tumbiana and Kylena lakes likely hosted oxygenic photosynthesizers, as well as methanotrophs and minor sulfate reducers. Hence environmental factors evidently affected the relative abundances of microbial groups. 


\section{Tables}

Table 1: Environmental characteristics

\begin{tabular}{|c|c|c|c|c|c|}
\hline Formation & $\begin{array}{c}\text { Depth } \\
\text { (substrate topography } \\
\text { and sed. thickness) }\end{array}$ & $\begin{array}{c}\text { Extent } \\
\text { (strike length) }\end{array}$ & $\begin{array}{c}\text { proportion of } \\
\text { exogenous siliciclastic } \\
\text { sediment }\end{array}$ & evaporation & tuff input \\
\hline Tumbiana & a few 10 s of meters & $\begin{array}{l}\text { many } 10 \text { s of } \\
\text { kilometers }\end{array}$ & little (mostly closed) & much (halite) & high \\
\hline Kylena & 10 meters & 10 kilometers & none (mostly closed) & some (carbonate) & high \\
\hline Hardey & a few 10 s of meters & a few kilometers & much (open) & none evident & none \\
\hline Mt Roe & a few meters & $<1$ kilometer & moderate (pulsed) & none evident & moderate \\
\hline Bellary & many 10 s of meters & a few kilometers & some (open) & none evident & none \\
\hline
\end{tabular}




\section{References}

Anderson TF, Raiswell R (2004) Sources and mechanisms for the enrichment of highly reactive iron in euxinic Black Sea sediments. American Journal of Science, 304, 203-233.

Asael D, Tissot FL, Reinhard CT, Rouxel O, Dauphas N, Lyons TW, Ponzevera E, Liorzou C, Chéron S (2013) Coupled molybdenum, iron and uranium stable isotopes as oceanic paleoredox proxies during the Paleoproterozoic Shunga Event. Chemical Geology, 362, 193-210.

Attridge EM, Rowell P (1997) Growth, heterocyst differentiation and nitrogenase activity in the cyanobacteria Anabaena variabilis and Anabaena cylindrica in response to molybdenum and vanadium. New Phytologist, 135, 517-526.

Awramik SM, Buchheim HP (2009) A giant, Late Archean lake system: the Mentheena Member (Tumbiana Formation; Fortescue Group), Western Australia. Precambrian Research, 174, 215-240.

Barley ME, Blake TS, Groves DI (1992) The Mount Bruce Megasequence Set and eastern Yilgarn Craton: examples of Late Archaean to Early Proterozoic divergent and convergent craton margins and controls on mineralization. Precambrian Research, 58, 55-70.

Beal EJ, Claire MW, House CH (2011) High rates of anaerobic methanotrophy at low sulfate concentrations with implications for past and present methane levels. Geobiology, 9, 131139.

Benton MJ (1995) Diversification and extinction in the history of life. Science, 268, 52-58.

Blake TS (1993) Late Archaean crustal extension, sedimentary basin formation, flood basalt volcanism and continental rifting: the Nullagine and Mount Jope Supersequences, Western Australia. Precambrian Research, 60, 185-241.

Blake TS, Barley ME (1992) Tectonic evolution of the late Archaean to early Proterozoic Mount Bruce Megasequence set, Western Australia. Tectonics, 11, 1415-1425.

Blake TS, Buick R, Brown SJA, Barley ME (2004) Geochronology of a late Archaean flood basalt province in the Pilbara craton, Australia: constraints on basin evolution, volcanic and sedimentary accumulation, and continental drift rates. Precambrian Research, 133, 143173.

Blättler CL, Kump LR, Fischer WW, Paris G, Kasbohm JJ, Higgins JA (2017) Constraints on ocean carbonate chemistry and $p \mathrm{CO}_{2}$ in the Archaean and Palaeoproterozoic. Nature Geoscience, 10, 41-45.

Bolhar R, van Kranendonk MJ (2007) A non-marine depositional setting for the northern Fortescue Group, Pilbara Craton, inferred from trace element geochemistry of stromatolitic carbonates. Precambrian Research, 155, 229-250.

Buick R (1992) The antiquity of oxygenic photosynthesis: evidence from stromatolites in sulphatedeficient Archaean lakes. Science, 255, 74-77.

Canfield DE, Raiswell R, Westrich JT, Reaves CM, Berner RA (1986) The use of chromium reduction in the analysis of reduced inorganic sulfur in sediments and shales. Chemical Geology, 54, 149-155.

Casciotti KL (2009) Inverse kinetic isotope fractionation during bacterial nitrite oxidation. Geochimica et Cosmochimica Acta, 73, 2061-2076.

Cerling TE (1994) Chemistry of closed basin lake waters: a comparison between African Rift Valley and some central North American rivers and lakes. In: Global geological record of lake basins (eds Gierlowski-Kordesch E, Kelts K). Cambridge University Press, pp. 29-30. 
Claire MW, Kasting JF, Domagal-Goldman SD, Stüeken EE, Buick R, Meadows VS (2014) Modeling the signature of sulfur mass-independent fractionation produced in the Archean atmosphere. Geochimica et Cosmochimica Acta, 141, 365-380.

Coffey JM, Flannery DT, Walter MR, George SC (2013) Sedimentology, stratigraphy and geochemistry of a stromatolite biofacies in the $2.72 \mathrm{Ga}$ Tumbiana Formation, Fortescue Group, Western Australia. Precambrian Research, 236, 282-296.

Czaja AD, Johnson CM, Beard BL, Eigenbrode JL, Freeman KH, Yamaguchi KE (2010) Iron and carbon isotope evidence for ecosystem and environmental diversity in the $\sim 2.7$ to $2.5 \mathrm{Ga}$ Hamersley Province, Western Australia. Earth and Planetary Science Letters, 292, 170180.

David LA, Alm EJ (2011) Rapid evolutionary innovation during an Archaean genetic expansion. Nature, 469, 93-96.

Dekov VM, Egueh NM, Kamenov GD, Bayon G, Lalonde SV, Schmidt M, Liebetrau V, Munnik F, Fouquet Y, Tanimizu M, Awaleh MO (2014) Hydrothermal carbonate chimneys from a continental rift (Afar Rift): Mineralogy, geochemistry, and mode of formation. Chemical Geology, 387, 87-100.

Eigenbrode JL, Freeman KH (2006) Late Archean rise of aerobic microbial ecosystems. Proceedings of the National Academy of Sciences, 103, 15759-15764.

Fay P, de Vasconcelos L (1974) Nitrogen metabolism and ultrastructure in Anabaena cylindrica. Archives of Microbiology, 99, 221-230.

Fischer WW, Schroeder S, Lacassie JP, Beukes NJ, Goldberg T, Strauss H, Horstmann UE, Schrag DP, Knoll AH (2009) Isotopic constraints on the Late Archean carbon cycle from the Transvaal Supergroup along the western margin of the Kaapvaal Craton, South Africa. Precambrian Research, 169, 15-27.

Flannery DT, van Kranendonk MJ, Mazumder R, Walter MR (2014) The ca 2.74 Ga Mopoke Member, Kylena Formation: a marine incursion into the northern Fortescue Group? Australian Journal of Earth Sciences, 61, 1095-1108.

Flannery DT, Walter MR (2012) Archean tufted microbial mats and the Great Oxidation Event: new insights into an ancient problem. Australian Journal of Earth Sciences, 59, 1-11.

Gislason SR, Eugster HP (1987) Meteoric water-basalt interaction. I: A laboratory study. Geochimica et Cosmochimica Acta, 51, 2827-2840.

Glass JB, Axler RP, Chandra S, Goldman CR (2012) Molybdenum limitation of microbial nitrogen assimilation in aquatic ecosystems and pure cultures. Frontiers in Microbiology, 3, doi:10.3389/fmicb.2012.00331.

Glass JB, Poret-Peterson AT, Wolfe-Simon F, Anbar AD (2013) Molybdenum Limitation Induces Expression of the Molybdate-Binding Protein Mop in a Freshwater Nitrogen-Fixing Cyanobacterium. Advances in Microbiology, 3 ID 37924.

Glass JB, Wolfe-Simon F, Elser JJ, Anbar AD (2010) Molybdenum-nitrogen co-limitation in freshwater and coastal heterocystous cyanobacteria. Limnology and Oceanography, 55, 667-676.

Greaney A, Rudnick RL, Gaschnig R (2016) Crustal sources of molybdenum. In: Goldschmidt conference, Yokohama, Japan.

Guy BM, Ono S, Gutzmer J, Kaufman AJ, Lin Y, Fogel ML, Beukes NJ (2012) A multiple sulfur and organic carbon isotope record from non-conglomeratic sedimentary rocks of the Mesoarchean Witwatersrand Supergroup, South Africa. Precambrian Research, 216-219, 208-231. 
Gysi AP, Stefansson A (2008) Numerical modelling of $\mathrm{CO}_{2}$-water-basalt interaction. Mineralogical Magazine, 72, 55-59.

Hahn KE, Turner EC, Babechuk MG, Kamber BS (2015) Deep-water seep-related carbonate mounds in a Mesoproterozoic alkaline lake, Borden Basin (Nunavut, Canada). Precambrian Research, 271, 173-197.

Hall CE (2005) SHRIMP U-Pb depositional age for the lower Hardey Formation: evidence for diachronous deposition of the lower Fortescue Group in the southern Pilbara region, Western Australia. Australian Journal of Earth Sciences, 52, 403-410.

Hayes JM (1994) Global methanotrophy at the Archean-Proterozoic transition. In: Early life on Earth. Nobel Symposium (ed Bengtson S). Columbia University Press, New York, pp. 220236.

Hayes JM, Kaplan IR, Wedeking KW (1983) Precambrian organic geochmistry, preservation of the record. In: Earth's earliest biosphere - its origin and evolution (ed Schopf JW). Princeton University Press, Princeton, NJ, pp. 93-134.

Hayes JM, Strauss H, Kaufman AJ (1999) The abundance of ${ }^{13} \mathrm{C}$ in marine organic matter and isotopic fractionation in the global biogeochemical cycle of carbon during the past $800 \mathrm{Ma}$. Chemical Geology, 161, 103-125.

Hinrichs KU (2002) Microbial fixation of methane carbon at $2.7 \mathrm{Ga}$ : Was an anaerobic mechanism possible? Geochemistry, geophysics, geosystems, 3, 1-10.

Hoefs J, Frey M (1976) The isotopic composition of carbonaceous matter in a metamorphic profile from the Swiss Alps. Geochimica et Cosmochimica Acta, 40, 945-951.

Horner-Devine MC, Lage M, Hughes JB, Bohannan BJ (2004) A taxa-area relationship for bacteria. Nature, 432, 750-753.

Ingerson E (1953) Nonradiogenic isotopes in geology: a review. Geological Society of America Bulletin, 64, 301-374.

Izon G, Zerkle AL, Zhelezinskaia I, Farquhar J, Newton RJ, Poulton SW, Eigenbrode JL, Claire MW (2015) Multiple oscillations in Neoarchaean atmospheric chemistry. Earth and Planetary Science Letters, 431, 264-273.

Jellison R, Miller LG, Melack JM, Dana GL (1993) Meromixis in hypersaline Mono Lake, California. II: Nitrogen fluxes. Limnology and Oceanography, 38, 1020-1039.

Kempe S, Kazmierczak J (2011) Soda lakes. In: Encyclopedia of Geobiology (eds Reitner J, Thiel V). Springer.

Kendall B, Dahl TW, Anbar A (2017) Good golly, why moly? The stable isotope geochemistry of molybdenum. Reviews in Mineralogy and Geochemistry, 82, 683-732.

Kenrick P, Crane PR (1997) The origin and early evolution of plants on land. Nature, 389, 33-39.

Kerrich R, Renaut RW, Bonli T (2002) Trace-element composition of cherts from alkaline lakes in the East African Rift: a probe for ancient counterparts. Society of Sedimentary Geology Special Publications, 73, 275-294.

Kharecha P, Kasting J, Siefert J (2005) A coupled atmosphere-ecosystem model of the early Archean Earth. Geobiology, 3, 53-76.

Koehler MC, Stüeken EE, Kipp MA, Buick R, Knoll AH (2017) Spatial and temporal trends in Precambrian nitrogen cycling: a Mesoproterozoic offshore nitrate minimum. Geochimica et Cosmochimica Acta, 198, 315-337.

Kral TA, Brink KM, Miller SL, McKay CP (1998) Hydrogen consumption by methanogens on the early Earth. Origins of Life and Evolution of the Biosphere, 28, 311-319. 
Krissansen-Totton J, Buick R, Catling DC (2015) A statistical analysis of the carbon isotope record from the Archean to Phanerozoic and implications for the rise of oxygen. American Journal of Science, 315, 275-316.

Kuga M, Carrasco N, Marty B, Marrocchi Y, Bernard S, Rigaudier T, Fleury B, Tissandier L (2014) Nitrogen isotopic fractionation during abiotic synthesis of organic solid particles. Earth and Planetary Science Letters, 393, 2-13.

Lalonde SV, Konhauser KO (2015) Benthic perspective on Earth's oldest evidence for oxygenic photosynthesis. Proceedings of the National Academy of Sciences, 112, 995-1000.

Lehman MR, Bernasconi SM, Barbieri A, McKenzie JA (2002) Preservation of organic matter and alteration of its carbon and nitrogen isotope composition during simulated and in situ early sedimentary diagenesis. Geochimica et Cosmochimica Acta, 66, 3573-3584.

Li L, Sherwood Lollar B, Li H, Wortmann UG, Lacrampe-Couloume G (2012) Ammonium stability and nitrogen isotope fractionations for $\mathrm{NH}_{4}{ }^{+}-\mathrm{NH}_{3(\mathrm{aq})}-\mathrm{NH}_{3 \text { (gas) }}$ systems at $20-70^{\circ} \mathrm{C}$ and $\mathrm{pH}$ of 2-13: applications to habitability and nitrogen cycling in low-temperature hydrothermal systems. Geochimica et Cosmochimica Acta, 84, 280-296.

Little C (1990) The terrestrial invasion: an ecophysiological approach to the origins of land animals, Cambridge University Press.

Londry KL, Dawson KG, Grover HD, Summons RE, Bradley AS (2008) Stable carbon isotope fractionation between substrates and products of Methanosarcina barkeri. Organic Geochemistry, 39, 608-621.

Luo G, Junium CK, Kump LR, Huang J, Li C, Feng Q, Shi X, Bai X, Xie S (2014) Shallow stratification prevailed for 1700 to $1300 \mathrm{Ma}$ ocean: Evidence from organic carbon isotopes in the North China Craton. Earth and Planetary Science Letters, 400, 219-232.

Lyons TW, Reinhard CT, Planavsky NJ (2014) The rise of oxygen in Earth's early ocean and atmosphere. Nature, 506, 307-315.

Lyons TW, Severmann S (2006) A critical look at iron paleoredox proxies: new insights from modern euxinic marine basins. Geochimica et Cosmochimica Acta, 70, 5698-5722.

Macfarlane AW, Danielson A, Holland HD (1994) Geology and major and trace element chemistry of late Archean weathering profiles in the Fortescue Group, Western Australia: implications for atmospheric $p \mathrm{O}_{2}$. Precambrian Research, 65, 297-317.

Martiny JBH, Bohannan BJ, Brown JH, Colwell RK, Fuhrman JA, Green JL, Horner-Devine MC, Kane M, Krumins JA, Kuske CR, Morin PJ (2006) Microbial biogeography: putting microorganisms on the map. Nature Reviews Microbiology, 4, 102-112.

McCready RGL, Gould WD, Barendregt RW (1983) Nitrogen isotope fractionation during the reduction of NO3-to NH4+ by Desulfovibrio sp. Canadian Journal of Microbiology, 29, 231-234.

McKirdy DM, Powell TG (1974) Metamorphic alteration of carbon isotopic composition in ancient sedimentary organic matter: new evidence from Australia and South Africa. Geology, 2, 591-595.

Moeller P, Bau M (1993) Rare-earth patterns with positive cerium anomaly in alkaline waters from Lake Van, Turkey. Earth and Planetary Science Letters, 117, 671-676.

Mook WG (2001) Environmental isotopes in the hydrological cycle, V. III, Surface water, IAEA Publish.

Moore H (1977) The isotopic composition of ammonia, nitrogen dioxide and nitrate in the atmosphere. Atmospheric Environment, 11, 1239-1243. 
Morgan B, Lahav O (2007) The effect of $\mathrm{pH}$ on the kinetics of spontaneous Fe(II) oxidation by $\mathrm{O}_{2}$ in aqueous solution-basic principles and a simple heuristic description. Chemosphere, 68 , 2080-2084.

Nägler TF, Anbar AD, Archer C, Goldberg T, Gordon GW, Greber ND, Siebert C, Sohrin Y, Vance D (2014) Proposal for an international molybdenum isotope measurement standard and data representation. Geostandards and Geoanalytical Research, 38, 149-151.

Neubert N, Nägler TF, Böttcher ME (2008) Sulfidity controls molybdenum isotope fractionation into euxinic sediments: Evidence from the modern Black Sea. Geology, 36, 775-778.

Nielsen LC, DePaolo DJ (2013) Ca isotope fractionation in a high-alkalinity lake system: Mono Lake, California. Geochimica et Cosmochimica Acta, 118, 276-294.

Nisbet EG, Grassineau NV, Howe CJ, Abell PI, Regelous M, Nisbet RER (2007) The age of Rubisco: the evolution of oxygenic photosynthesis. Geobiology, 5, 311-335.

Paul D, Skrzypek G, Forizs I (2007) Normalization of measured stable isotopic compositions to isotope reference scales-a review. Rapid Communications in Mass Spectrometry, 21, 3006-3014.

Planavsky NJ, Asael D, Hofmann A, Reinhard CT, Lalonde SV, Knudsen A, Wang X, Ossa Ossa F, Pecoits E, Smith AJB, Beukes NJ, Bekker A, Johnson TM, Konhauser K, Lyons TW, Rouxel OJ (2014) Evidence for oxygenic photosynthesis half a billion years before the Great Oxidation Event. Nature Geoscience, 7, 283-286.

Poulson RL, Siebert C, McManus J, Berelson WM (2006) Authigenic molybdenum isotope signatures in marine sediments. Geology, 34, 617-620.

Poulton SW, Canfield DE (2005) Development of a sequential extraction procedure for iron: implications for iron partitioning in continentally derived particulates. Chemical Geology, 214, 209-221.

Poulton SW, Canfield DE (2011) Ferruginous conditions: a dominant feature of the ocean through Earth's history. Elements, 7, 107-112.

Poulton SW, Raiswell R (2002) The low-temperature geochemical cycle of iron: from continental fluxes to marine sediment deposition. American Journal of Science, 302, 774-805.

Rainey PB, Travisano M (1998) Adaptive radiation in a heterogeneous environment. Nature, 394, 69-72.

Raiswell R, Canfield DE (1998) Sources of iron for pyrite formation in marine sediments. American Journal of Science, 298, 219-245.

Rasmussen B, Buick R (1999) Redox state of the Archean atmosphere: Evidence from detrital heavy minerals in ca. 3250-2750 Ma sandstones from the Pilbara Craton, Australia. Geology, 27, 115-118.

Reinhard CT, Lyons TW, Rouxel O, Asael D, Dauphas N, Kump LR (2013) Iron Speciation and Isotope Perspectives on Palaeoproterozoic Water Column Chemistry. In: Reading the Archive of Earth's Oxygenation (eds Kump LR, Kuznetsov AB, Gorokhov IM, Melezhik VA, Farkaš J, Chakrabarti R, Jacobsen SB, Reinhard CT, Lyons TW, Rouxel O, Asael D, Dauphas N, van Zuilen M, Schoenberg R, Tissot FLH, Hannah JL, Stein HJ). Springer Berlin, pp. 1483-1492.

Reinhard CT, Raiswell R, Scott CT, Anbar A, Lyons TW (2009) A late Archean sulfidic sea stimulated by early oxidative weathering of the continents. Science, 326, 713-716.

Rudnick RL, Gao S (2014) Composition of the continental crust. Treatise on Geochemistry, 4, 151. 
Rye R, Holland HD (2000) Life associated with a 2.76 Ga ephemeral pond?: Evidence from Mount Roe \#2 paleosol. Geology, 28, 483-486.

Sakurai R, Ito MU, Y., Kitajima K, Maruyama S (2005) Facies architecture and sequencestratigraphic features of the Tumbiana Formation in the Pilbara Craton, northwestern Australia: implications for depositional environments of oxygenic stromatolites during the Late Archean. Precambrian Research, 138, 255-273.

Schidlowski M (1987) Application of stable carbon isotopes to early biochemical evolution on Earth. Annual Review of Earth and Planetary Sciences, 15, 47-72.

Siebert C, McManus J, Bice A, Poulson R, Berelson WM (2006) Molybdenum isotope signatures in continental margin marine sediments. Earth and Planetary Science Letters, 241, 723733.

Sigman DM, Karsh KL, Casciotti KL (2009) Ocean process tracers: nitrogen isotopes in the ocean. In: Encyclopedia of ocean science. Elsevier, Amsterdam.

Slotznick SP, Fischer WW (2016) Examining Archean methanotrophy. Earth and Planetary Science Letters, 441, 52-59.

Smith RE, Perdrix JL, Parks TC (1982) Burial metamorphism in the Hamersley Basin, Western Australia. Australian Journal of Petrology, 23, 75-102.

Smith VH, Foster BL, Grover JP, Holt RD, Leibold MA (2005) Phytoplankton species richness scales consistently from laboratory microcosms to the world's oceans. Proceedings of the National Academy of Sciences, 102, 4393-4396.

Stein A, Gerstner K, Kreft H (2014) Environmental heterogeneity as a universal driver of species richness across taxa, biomes and spatial scales. Ecology Letters, 17, 866-880.

Stüeken EE (2013) A test of the nitrogen-limitation hypothesis for retarded eukaryote radiation: nitrogen isotopes across a Mesoproterozoic basinal profile. Geochimica et Cosmochimica Acta, 120, 121-139.

Stüeken EE, Buick R, Guy BM, Koehler MC (2015a) Isotopic evidence for biological nitrogen fixation by Mo-nitrogenase at 3.2 Gyr. Nature, 520, 666-669.

Stüeken EE, Buick R, Schauer AJ (2015b) Nitrogen isotope evidence for alkaline lakes on late Archean continents. Earth and Planetary Science Letters, 411, 1-10.

Stüeken EE, Catling DC, Buick R (2012) Contributions to late Archaean sulphur cycling by life on land. Nature Geoscience, 5, 722-725.

Taylor SR, McLennan SM (1995) The geochemical evolution of continental crust. Reviews of Geophysics, 33, 241-265.

Tesdal JE, Galbraith ED, Kienast M (2013) Nitrogen isotopes in bulk marine sediment: linking seafloor observations with subseafloor records. Biogeosciences, 10, 101-118.

Thomazo C, Ader M, Farquhar J, Philippot P (2009) Methanotrophs regulated atmospheric sulfur isotope anomalies during the Mesoarchean (Tumbiana Formation, Western Australia). Earth and Planetary Science Letters, 279, 65-75.

Thomazo C, Ader M, Phillippot P (2011) Extreme ${ }^{15} \mathrm{~N}$-enrichment in 2.72-Gyr-old sediments: evidence for a turning point in the nitrogen cycle. Geobiology, 9, 107-120.

Thomazo C, Papineau D (2013) Biogeochemical cycling of nitrogen on the early Earth. Elements, 9, 345-351.

Tice MM, Lowe DR (2006) The origin of carbonaceous matter in pre-3.0 Ga greenstone terrains: A review and new evidence from the 3.42 Ga Buck Reef Chert. Earth-Science Reviews, 76, 259-300. 
Voegelin AR, Pettke T, Greber ND, von Niederhäusern B, Nägler TF (2014) Magma differentiation fractionates Mo isotope ratios: evidence from the Kos Plateau Tuff (Aegean Arc). Lithos, 190, 440-448.

Watanabe Y, Bevacqua DC, Ohmoto H (2004) Microbial ecosystem in the oldest freshwater lake revealed from a drill core of the 2.76 Ga Hardey Formation, Pilbara District, Western Australia. AGU Fall Meeting Abstracts, 1, 0996.

Whitaker RJ, Grogan DW, Taylor JW (2003) Geographic barriers isolate endemic populations of hyperthermophilic archaea. Science, 301, 976-978.

White AJR, Legras M, Smith RE, Nadoll P (2014a) Deformation-driven, regional-scale metasomatism in the Hamersley Basin, Western Australia. Journal of Metamorphic Petrology, 32, 417-433.

White AJR, Smith RE, Nadoll P, Legras M (2014b) Regional-scale metasomatism in the Fortescue Group volcanis, Hamersley Basin, Western Australia: implications for hydrothermal ore systems. Journal of Petrology, 55, 977-1009.

Wille M, Nebel O, Van Kranendonk MJ, Schoenberg R, Kleinhanns IC, Ellwood MJ (2013) MoCr-isotope evidence or a reducing Archean atmosphere in 3.46-2.76 Ga black shales from the Pilbara, Western Australia. Chemical Geology, 340, 68-76.

Yamaguchi KE (2002) Geochemistry of Archean-Paleoproterozoic black shales: the early evolution of the atmosphere, oceans, and biosphere. PhD dissertation, Department of Geosciences, Pennsylvania State University, pp. 485.

Yang W, Holland HD, Rye R (2002) Evidence for low or no oxygen in the late Archean atmosphere from the $2.76 \mathrm{Ga}$ Mt. Roe\# 2 paleosol, Western Australia: Part 3. Geochimica et Cosmochimica Acta, 66, 3707-3718.

Zavarzin GA (1993) Epicontinental soda lakes as probable relict biotopes of terrestrial biota formation. Microbiology, 62, 473-479.

Zerkle A, House CH, Brantley SL (2005) Biogeochemical signatures through time as inferred from whole microbial genomes. American Journal of Science, 305, 467-502.

Zerkle AL, Claire MW, Domagal-Goldman SD, Farquhar J, Poulton SW (2012) A bistable organic-rich atmosphere on the Neoarchaean Earth. Nature Geoscience, 5, 359-363.

Zerkle AL, House CH, Cox RP, Canfield DE (2006) Metal limitation of cyanobacterial N2 fixation and implications for the Precambrian nitrogen cycle. Geobiology, 4, 285-297.

Zerkle AL, Scheiderich K, Maresca JA, Liermann LJ, Brantley SL (2011) Molybdenum isotope fractionation by cyanobacterial assimilation during nitrate utilization and $\mathrm{N}_{2}$ fixation. Geobiology, 9, 94-106.

Zhang X, Sigman DM, Morel FM, Kraepiel AM (2014) Nitrogen isotope fractionation by alternative nitrogenases and past ocean anoxia. Proceedings of the National Academy of Sciences, 111, 4782-4787. 